\title{
GEOTHERMAL DEVELOPMENT PLAN: MARICOPA COUNTY
}

\author{
by \\ The Arizona Geothermal Commercialization Team \\ Don H. White, Ph.D., Principal Investigator \\ Larry A. Goldstone, Project Manager \\ Arizona Geological Survey \\ Open-File Report 79.8
}

\section{Arizona Geological Survey}

416 W. Congress, Suite \#100, Tucson, Arizona 85701

State Contractor:

Arizona Solar Energy Commission

James F. Warnock, Jr, Director

Frank Mancini, Ph.D., Associate Director

1700 West Washington Phoenix, Arizona 85007

Work performed under

Contract No. DE-FC03-80RA50076

Modification No. A-001 Evaluation of Geothermal Energy in Arizona

U.S. Department of Energy San Francisco Office Region IX

Subcontract 114-80 with Department of Chemical Engineering

This report is preliminary and has not been edited

or reviewed for conformity with Arizona Geological Survey standards 
' 


\section{ACKNOWLEDGEMENTS}

The Arizona Geothermal Commercialization Team has been comprised of many individuals over the past several years. Recognition is extended to the following professors who have contributed to the Team's efforts: John Kessler, Ph.D.; Mike Pasqualetti, Ph.D.; and David Wolf, Ph.D.

Group leaders were Mohamad Chehab, Larry Goldstone, Lani Malysa and Bill Weibel.

Other contributors include Cherif Ballamane, Ronda Bitterli, Wei-hsin (Alex) Chung, Elizabeth Foster, Jeff Hagen, Akram Hasan, Greta Jensen, Gary Kyle, Timeral Rowe, Edward Seames and John Westover. The following people were special task contributors: Don Astrom, Greta Jensen, Iftikhar Khan, Doug Linkhart, Lani Malysa, Mobin Qaheri, Xavier Suarez, Charles Tabet and Steve Unguran.

In addition, W. Richard Hahman, Sr., Claudia Stone and Jim Witcher of the Arizona Bureau of Geology and Mineral Technology-Geothermal Group deserve recognition for their contributions and assistance.

Special thanks are extended to Bette Holt for drafting some of the figures and to Peggy Jackson and Lee DeYonghe for their assistance in typing the final manuscript. 


.


LIST OF FIGURES . . . . . . . . . . . . . . . . . . . . ii

LIST OF TABLES . . . . . . . . . . . . . . . . . . iii

INTRODUCTION . . . . . . . . . . . . . . . . . 1

AREA DEVELOPMENT PLANS . . . . . . . . . . . . . . . 2

GEOTHERMAL RESOURCES . . . . . . . . . . . . . . . 2

ECONOMY ............................

Population ....................... . . . 8

Growth . . . . . . . . . . . . . . . . . . . 8

Industry and Employment . . . . . . . . . . . . . 8

Income . . . . . . . . . . . . . . . . . . . 12

Other Economic Indicators . . . . . . . . . . . . . . 12

LAND OWNERSHIP . . . . . . . . . . . . . . . 16

ENERGY USE . . . . . . . . . . . . . . . . . 18

WATER ....................... 24

MATCHING GEOTHERMAL RESOURCES TO POTENTIAL USERS . • . . • . . 27

Soft Drink Industry . . . . . . . . . . . . . . . 43

Ready-Mix Concrete Industry . . . . . . . . . . . . . . 44

Beet Sugar Industry .................... 44

Ice Cream and Frozen Desserts . . . . . . . . . . . . 46

Cottonseed Oil Mills .................. . . 47

Animal and Marine Fats and Oils . . . . . . . . . . . 48

Plating and Polishing Industry . . . . . . . . . . . . 49

APPENDIX A . . . . . . . . . . . . . . . . 50

APPENDIX B . . . . . . . . . . . . . . . . . 52

BIBLIOGRAPHY . . . . . . . . . . . . . . . 57 



\section{LIST OF FIGURES}

Figure

Page

1 Area Development Plans for Arizona

3

2 Arizona's Proven, Potential and Inferred Resources 4

3 Population Projections for Maricopa County 9

4 Major Employment Sector Projections for Maricopa County 13

5 Other Employment Sector Projections for Maricopa County 14

6 Projections of Personal Income (1972 Dollars) for Maricopa County

7 Projections of Personal Per Capita Income (1972 Dollars) for Maricopa County

8 General Land Ownership Map for Maricopa County 17

9 Monthly Electric Power Sales by Salt River Project in Maricopa County (1978)

10 Growth in the Daily Electrical Peak 25

il Projected Alternatives for Water Use in Maricopa County 26

12 Projected Geothermal Heat on Line Under Private Development 38

13 Projected Geothermal Heat on Line Under City Development 39

14 Projected Growth of Metropolitan Phoenix 41 

Table

$\underline{\text { Page }}$

1 Some Common Conversion Factors

2. Proven and Potential Reservoirs of Maricopa County Less Than $1.2 \mathrm{Km}$ Depth

3 Inferred Intermediate to High Temperature $\left(>90^{\circ} \mathrm{C}\right)$ Geothermal Reservoirs of Maricopa County of Less Than 2.5. Km Depth

4 Towns in Maricopa County and Their Estimated Populations

5 Land Ownership in Maricopa County

6 Maricopa County Energy-Use Projections

7 Est. Average Energy Prices by User Class, 1979

8 Real Price Growth Rates

9 Cooling and Heating Degree Days for Selected Towns in Maricopa County

10 Assumptions for Geothermal Heating for Commercial Buildings 30

11 Cost Comparison and Summary: Geothermal Space Heating for Commercial Facilities - Goodyear/Avondale

12 Assumptions for Residential Geothermal Heating

13 Cost Comparison and Summary: Geothermal Space Heating for the Residential Sector - Litchfield Park

14 Estimated Process Heat Energy Requirements for Selected Industries in Maricopa County

15 Barrels of Oil Replaced by Geothermal Energy per Year Process Heat Market

16 Agribusiness in Maricopa County

17 Cottonseed Oil Mills Energy End-Use Requirements 48

18 Fats and Oils Energy End-Use Requirements 49 
INTRODUCTION

Alternative sources of energy will have to be developed as the availability of traditional energy resources continues to diminish. Arizona is supplied with geothermal reserves which potentially could supplement the existing energy supplies. Consequently, planning efforts have concentrated on estimating the potential of geothermal energy utilization in Arizona and in providing information necessary for its prospective commercialization.

Geothermal commercialization plans were prepared for seven distinct intrastate subdivisions. The geothermal resource prospect and the potential geothermal uses for each area are discussed in separate Area Development Plans (ADPs). The major objective of the ADP is to provide information for the prospective development and commercialization of geothermal energy for the specified areas. Attempts are made to match the available geothermal resources to potential residential, commercial, industrial and agricultural users.

Maricopa County is the area of Arizona receiving top priority since it contains over half of the state's population. The county is located entirely within the Basin and Range physiographic region in which geothermal resources are known to occur. Several approaches were taken to match potential users to geothermal resources. One approach involved matching some of the largest facilities in the county to nearby geothermal resources. Other approaches involved identifying industrial processes whose heat requirements are less than the average assessed geothermal reservoir temperature of $110^{\circ} \mathrm{C}\left(230^{\circ} \mathrm{F}\right)$. Since many of the Industries are located on or near geothermal. resources, geothermal energy potentially could be adapted to many industrial processes. 
AREA DEVELOPMENT PLANS

Arizona has been divided into seven distinct single or multicounty subdivisions for which Area Development Plans (ADPs) for geothermal commercialization have been developed. A map of Arizona presented in Figure 1 shows these areas which are numbered in order of planning priority.

This report is concerned with Maricopa County. Both metric and English units are provided in the text. However, only metric units appear in the tables and figures. For convenience, some common conversion factors are listed in Table 1 . In this report, one milion Btu $=\mathrm{MB}$ tu.

\section{TABLE 1: SOME COMMON CONVERSION FACTORS}

Length and Volume Conversions:

To Convert:

meters

kilometers

cubic kilometers

liters
Multiply By:

3.281

0.6214

0.2399

0.2642
To Obtain:

feet

miles

cubic miles

gallons

Temperature Conversions: ${ }^{\circ} F=\left(1.8 \times{ }^{\circ} \mathrm{C}\right)+32$

GEOTHERMAL RESOURCES

Maricopa County lies entirely within the Basin and Range physiographic province which is characterized by numerous mountain ranges rising abruptly from broad valleys. Thirteen areas known to store thermal water at relatively shallow depths of less than $1200 \mathrm{~m}$ (3937 ft) are located within Maricopa County. Numbered boxes in Figure 2 identify these areas; Table 2 gives the location of each of these areas along with rough estimates of depth, volume and temperature. 


\section{Prlorteles}

I) Maricopa

II) PIma

III) Graham/Greenlee

IV) Plaal

V) Tma

VI) Cochise/Santa Cruz

VII) Northern Counties $(1,3,4,8,9,13)$

\section{County Names}

1. Apache

2. Cochise

3. Coconino

4. G11a

5. Graham

6. Greenlee

7. Maricopa

8. Mohave

9.- Navajo

10. Pima

11. Pinal

12. Santa Cruz

13. Yavapa1

14. Yuma

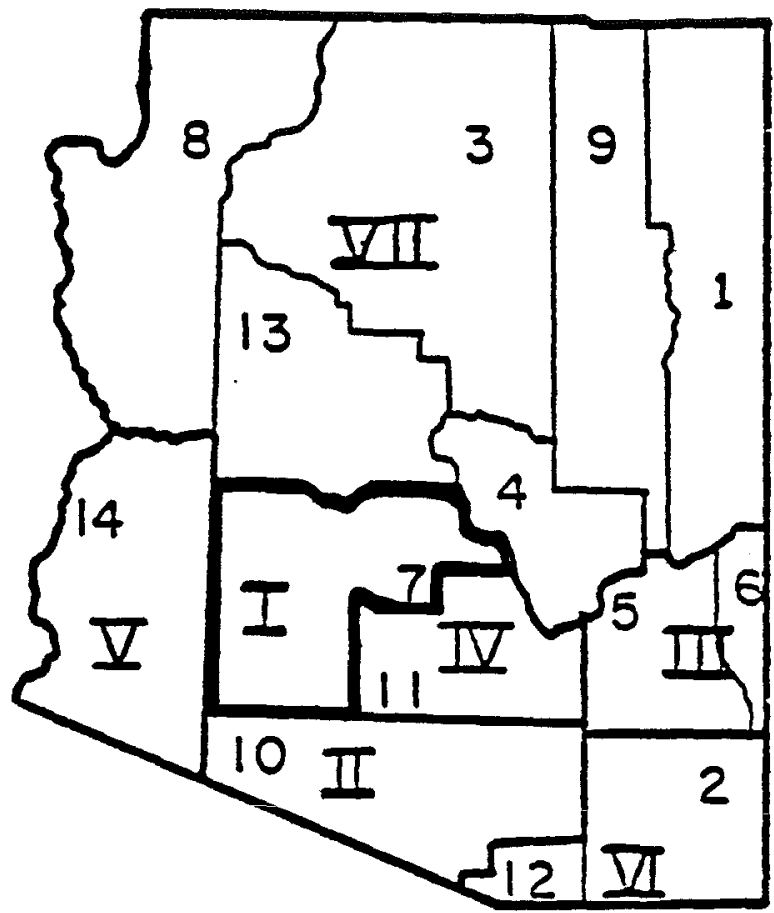

Figure 1: Area Development Plans for Arizona. 


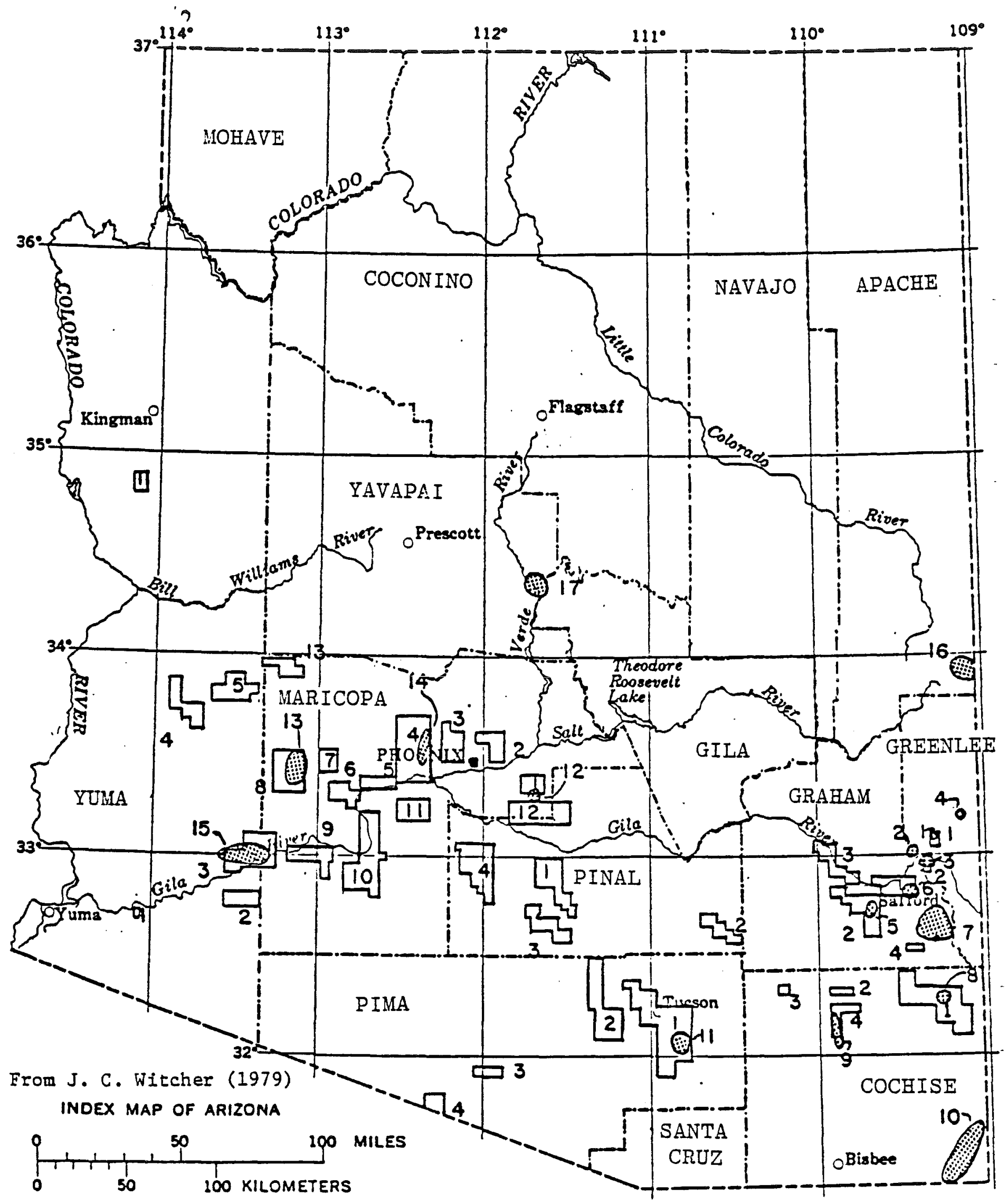

Figure 2: Arizona's Proven, Potential and Inferred Resources. 
TABLE 2: PROVEN AND POTENTTAL RESERVOIRS OF MARICOPA COUNTY LESS THAN 1.2 KM DEPTH (Modified from Witcher, 1979)

$\operatorname{Tr}$ - Average reservoir temperature

\begin{tabular}{|c|c|c|c|c|c|c|c|}
\hline Area & Location & Volume $\mathrm{km}^{3}$ & Temperature ${ }^{\circ} \mathrm{C}$ & $\begin{array}{l}\text { Depth } \\
(\mathrm{km})\end{array}$ & $\operatorname{Tr}-{ }^{\circ} \mathrm{C}$ & $\begin{array}{l}\text { Geothermometry } \\
\text { Temperature }{ }^{\mathrm{O}} \mathrm{C}\end{array}$ & Method \\
\hline 1 & T1N, T1S, R6-7E & 46.4 & $30-40$ & $<0.15$ & 60 & $50-60$ & Chalcedony \\
\hline 2 & $\mathrm{~T} 2-3 \mathrm{~N}, \mathrm{R} 3-5 \mathrm{E}$ & 68.1 & $30-45$ & $<0.46$ & 60 & $30-60$ & Cha1cedony \\
\hline 3 & $\mathrm{~T} 2-3 \mathrm{~N}, \mathrm{R} 1-2 \mathrm{E}$ & 55.7 & $30-45$ & $<0.61$ & 60 & $35-60$ & Chalcedony \\
\hline 4 & $\mathrm{~T} 1-4 \mathrm{~N}, \mathrm{R} 1-2 \mathrm{~W}$ & 222.9 & $30-60$ & $<0.61$ & 60 & $30-70$ & Chalcedony \\
\hline 5 & T1N, T1S, R3-4W & 37.1 & $30-40$ & $<0.61$ & 55 & $30-40$ & Chalcedony \\
\hline 6 & $\mathrm{~T} 1-2 \mathrm{~S}, \mathrm{R} 5-6 \mathrm{~W}$ & 52.6 & $30-35$ & $<0.46$ & 70 & $40-70$ & Chalcedony \\
\hline 7 & $\mathrm{~T} 1-2 \mathrm{~N}, \mathrm{R} 6-7 \mathrm{~W}$ & 49.5 & $30-50$ & $<0.21$ & 75 & $45-85$ & $\begin{array}{c}\text { Quartz; } \\
-\mathrm{K}-\mathrm{Ca} / \mathrm{Mg} \text { corr. }\end{array}$ \\
\hline 8 & T1S, T1-2N, R8-10W & 148.6 & $30-40$ & $<0.61$ & 65 & $30-110$ & Chalcedony \\
\hline 9 & $T 4-6 \mathrm{~S}, \mathrm{R} 7-9 \mathrm{~W}$ & 74.3 & $30-40$ & $<0.30$ & 60 & $30-80$ & Chalcedony \\
\hline 10 & $\mathrm{~T} 2-7 \mathrm{~S}, \mathrm{R} 3-6 \mathrm{~W}$ & 182.7 & $30-50$ & $<0.61$ & 60 & $30-65$ & Chalcedony \\
\hline 11 & $\mathrm{~T} 2-3 \mathrm{~S}, \mathrm{R} 1-2 \mathrm{~W}$ & 74.3 & $30-40$ & $<0.46$ & 60 & $30-70$ & Chalcedony \\
\hline 12 & $\mathrm{~T} 2-3 \mathrm{~S}, \mathrm{R} 5-8 \mathrm{E}$ & 123.8 & $30-40$ & $<0.30$ & 60 & $40-60$ & Chalcedony \\
\hline 13 & $\mathrm{~T} 6-7 \mathrm{~N}, \mathrm{R} 8-10 \mathrm{~W}$ & 61.9 & $30-40$ & $<0.61$ & 55 & $30-40$ & Chalcedony \\
\hline
\end{tabular}


Normal temperature changes with depth (i.e., temperature gradients) in the Basin and Range province range from $35^{\circ} \mathrm{C} / \mathrm{km}\left(153^{\circ} \mathrm{F} / \mathrm{mi}\right)$ to $50^{\circ} \mathrm{C} / \mathrm{km}\left(196^{\circ} \mathrm{F} / \mathrm{mi}\right)$. Therefore, important geothermal reservoirs may occur where permeable rocks are water-saturated and deeper than $300 \mathrm{~m}(984 \mathrm{ft})$. Shallower geothermal resources can result when temperature gradients or hydraulic pressure cause this deep hot water to flow upward along fault zones and into shallow aquifers. In Mesa, eight pumped wells ranging from $90 \mathrm{~m}$ (312 ft) to $300 \mathrm{~m}$ (984 ft) deep produce $37^{\circ} \mathrm{C}\left(99^{\circ} \mathrm{F}\right)$ to $54^{\circ} \mathrm{C}\left(129^{\circ} \mathrm{F}\right)$ water. In the Western Salt River Valley, pumped wells $300 \mathrm{~m}\left(984 \mathrm{ft}\right.$ ) to $600 \mathrm{~m}$ (1968 ft) deep discharge $35^{\circ} \mathrm{C}$ $\left(95^{\circ} \mathrm{F}\right.$ ) to $56^{\circ} \mathrm{C}\left(133^{\circ} \mathrm{F}\right)$ water. In the Chandler-Williams Air Force Base area, two deep geothermal test wells, 1 Power Ranches and 2 Power Ranches, have been drilled. Geophysical logs on file at the Arizona Oil and Gas Conservation Commission, Phoenix, show a $117.8^{\circ} \mathrm{C}\left(244^{\circ} \mathrm{F}\right)$ temperature at $2768 \mathrm{~m}$ (9081 ft) and a $120^{\circ} \mathrm{C}\left(248^{\circ} \mathrm{F}\right)$ temperature at $2783 \mathrm{~m}(9130 \mathrm{ft})$ for 1 Power Ranches and 2 Power Ranches, respectively.

Intermediate temperature geothermal potential is inferred from presently available geological, geochemical and geophysical information (Witcher, 1979). The locations of these inferred potential reservoirs and rough estimates of depth, volume and temperature are listed in Table 3 .

A forthcoming state geothermal map compiled by the Arizona Bureau of Geology and Mineral Technology and published by the National Oceanographic and Atmospheric Administration will provide a complete and updated listing of data concerning thermal well and spring locations in Arizona as well as temperature and depth estimates, flow rates and total disolved solids. This map will be available in late 1981. 
TABLE 3: INFERRED INTERMEDIATE TO HIGH TEMPERATURE ( $>90^{\circ} \mathrm{C}$ ) GEOTHERMAL RESERVOTRS OF MARICOPA COUNTY OF LESS THAN $2.5 \mathrm{KM}$ DEPTH

$\operatorname{Tr}$ - Average reservolr temperature

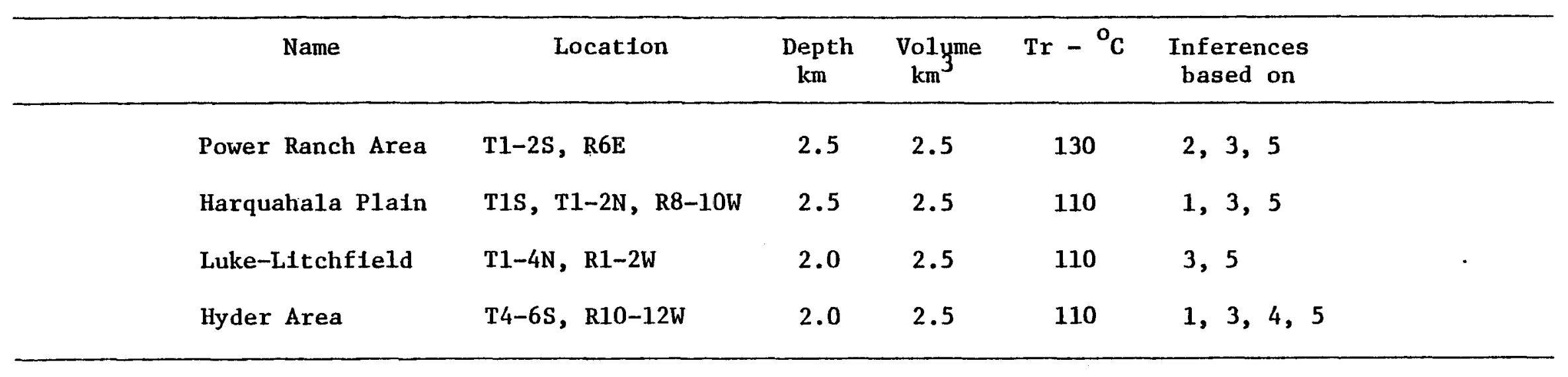
(1) Geothermometry
(2) Deep we11 tests
(3) Geophys1cs/heat flow
(4) Young volcanism
(5) Structure 
ECONOMY

\section{Population}

Maricopa County ranks first in priority in Arizona primarily because it supports over half of the state's population. The 1980 population for Maricopa County was 1,508,030 people. Its total land area of 9,226 square miles gives Maricopa County a population density of 163.5 persons per square mile. However, this can be misleading in that over 90 percent of the total population of the county lies within a 20-mile radius of Phoenix. Ethnic breakdown of the population is 80 percent white, 15 percent Hispanic, 3.5 percent black, and one percent Indian.

Growth

Over the last 30 years the population of Maricopa County has grown at an implied annual rate of 5.7 percent. Future projections for Maricopa County place population growth between two and three percent per year to the year 2000. with growth slowing slightly after 2000. Figure 3 shows projected population growth for the years 1970 to 2020 as approved by the Technical Advisory Committee of the Arizona Department of Economic Security on May 31, 1979. However, due to the energy situation in the Northeast and Midwest, this rate of population growth could be exceeded as newcomers move to the sunbelt in search of a warmer climate. The largest towns in Maricopa County are listed in Table 4 along with their estimated populations and growth rates per year from 1975 to 2000 as estimated from information provided by the Maricopa Association of Governments.

\section{Industry and Employment}

The principal contributor to Maricopa County's economy is manufacturing, specifically the manufacture of high technology products. Manufacturing ac- 


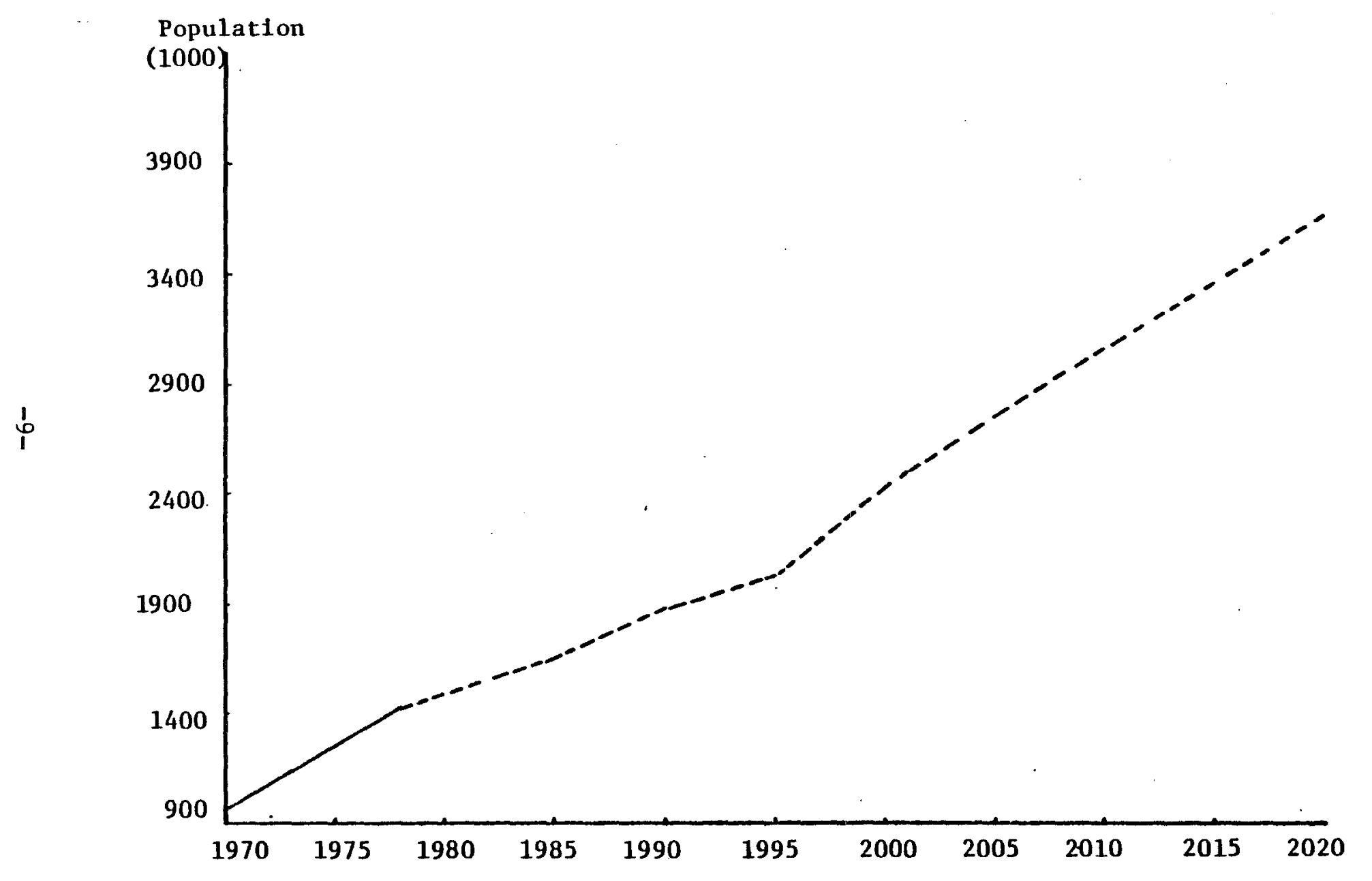

Figure 3: Population Projections for Maricopa County to 2020. Source: Technical Advisory Committee (DES) 
TABLE 4: TOWNS IN MARICOPA COUNTY AND THEIR ESTIMATED POPULATIONS

\begin{tabular}{|c|c|c|}
\hline City & $\begin{array}{l}\text { Population } \\
\text { (1975) }\end{array}$ & $\begin{array}{l}\text { Growth Rate per } \\
\text { year to } 2000 \text { (1) }\end{array}$ \\
\hline Avondale & 11,405 & $10.5 \%$ \\
\hline Buckeye & 2,675 & $8.3 \%$ \\
\hline Cashion & $4,280 \quad(2)$ & $5.0 \%(3)$ \\
\hline Cave Creek/Carefree & $2,150(2)$ & $5.0 \%(3)$ \\
\hline Chandler & 22,496 & $12.0 \%$ \\
\hline E1 Mirage & 3,827 & $10.6 \%$ \\
\hline Gila Bend & 2,300 & $4.3 \%$ \\
\hline Gilbert & 7,091 & $22.0 \%$ \\
\hline Glendale & 71,292 & $4.25 \%$ \\
\hline Goodyear & 3,187 & $29.0 \%$ \\
\hline Guadalupe & 4,285 & $4.3 \%$ \\
\hline Litchfield Park & $3,100(2)$ & $5.0 \% \quad(3)$ \\
\hline Mesa & 117,099 & $2.5 \%$ \\
\hline Paradise Valley & 11,532 & $2.0 \%$ \\
\hline Peoria & 13,527 & $15.5 \%$ \\
\hline Phoenix & 699,006 & $2.0 \%$ \\
\hline Scottsdale & 78,065 & $1.03 \%$ \\
\hline Sun City & $43,500 \quad(2)$ & $5.0 \%(3)$ \\
\hline Surprise & 3,400 & $4.85 \%$ \\
\hline Tempe & 94,063 & $3.34 \%$ \\
\hline Tolleson & 3,778 & $17.1 \%$ \\
\hline Wickenburg & 2,908 & $5.0 \%(3)$ \\
\hline Young town & 2,000 & $5.0 \%$ \\
\hline
\end{tabular}

1. Maricopa Association of Govermments

2. Valley National Bank (1977 data)

3. Estimated growth rate of five percent based on historic county growth 
counted for an estimated 91,000 jobs in the county in 1979 or about 17 percent of the labor force. Value added by manufacturing was estimated at just over $\$ 3$ billion for 1979 , or a 15 percent gain over 1978. Most of this activity was concentrated in the Phoenix metropolitan area. The Department of Economic Security estimates that employment in the manufacturing sector will grow by five percent per year through the year 2000. This five percent annual growth rate will occur mostly in the basic employment sector as a result of growth in the electronics and aircraft industries. Because growth in the basic employment sector will be strong, the general economy of Maricopa County should remain healthy through the year 2000 .

The second largest contributor to the economy of Maricopa County is tourism and travel. Tourism showed a 22-percent gain in 1978 over 1977 and was expected to show a 10-percent gain in 1979. Reports showed that the tourist industry realized $\$ 1.68$ billion in revenue in 1978 and provided about 180,000 jobs for Maricopa County residents.

In dollar figures, agriculture is the third largest industry in Maricopa County. Approximately 510,000 acres of the county are used for agriculture, 50 percent of which was planted in cotton and the rest divided between wheat, hay, vegetables and fruits (mostly citrus). The total value of crops and livestock exceeds \$1 billion annually.

The Department of Economic Security estimates that employment in agriculture will decline over the next 20 years at an average rate of 1.7 percent per year. This reflects the problems of water availability, since agriculture uses 90 percent of the county's water. Also, the high value of land for non-agricultural purposes will force the amount of agricultural acreage downward in the future. 
Figures 4 and 5 present the projected growth of employment for various sectors of the economy through the year 2000. Total employment is projected to rise by four percent per year with major contributions coming from the construction industry, manufacturing and civilian government. In addition, strong growth is anticipated in the basic employment sector which reflects a strong economy and provides a basis for other types of employment growth in the county.

\section{Income}

Personal income and per capita income are considered strong indicators of the economic health of a region. Since there is a direct relationship between income and energy consumption, changes in personal income and per capita income are a reflection of both economic growth and energy consumption. During the period 1970 to 1977, aggregate personal income in Maricopa County was increasing (in real terms) by 10 percent per year, and as Figure 6 shows, this trend is expected to continue to the year 2000. This fact is not surprising when one looks at the increasing importance of the construction industry, manufacturing and government employment in Maricopa County. These sectors tend to pay high wages to their employees which in turn fuels the regional economy.

Personal per capita income has also increased steadily in the last decade. Figure 7 is a plot of the projected increase in real per capita income to the year 2000. The steady growth represents a real annual increase of

\section{5 percent per year.}

\section{Other Economic Indicators}

In addition to the major economic indicators such as population, employment and income, there are other indicators of the general welfare of 


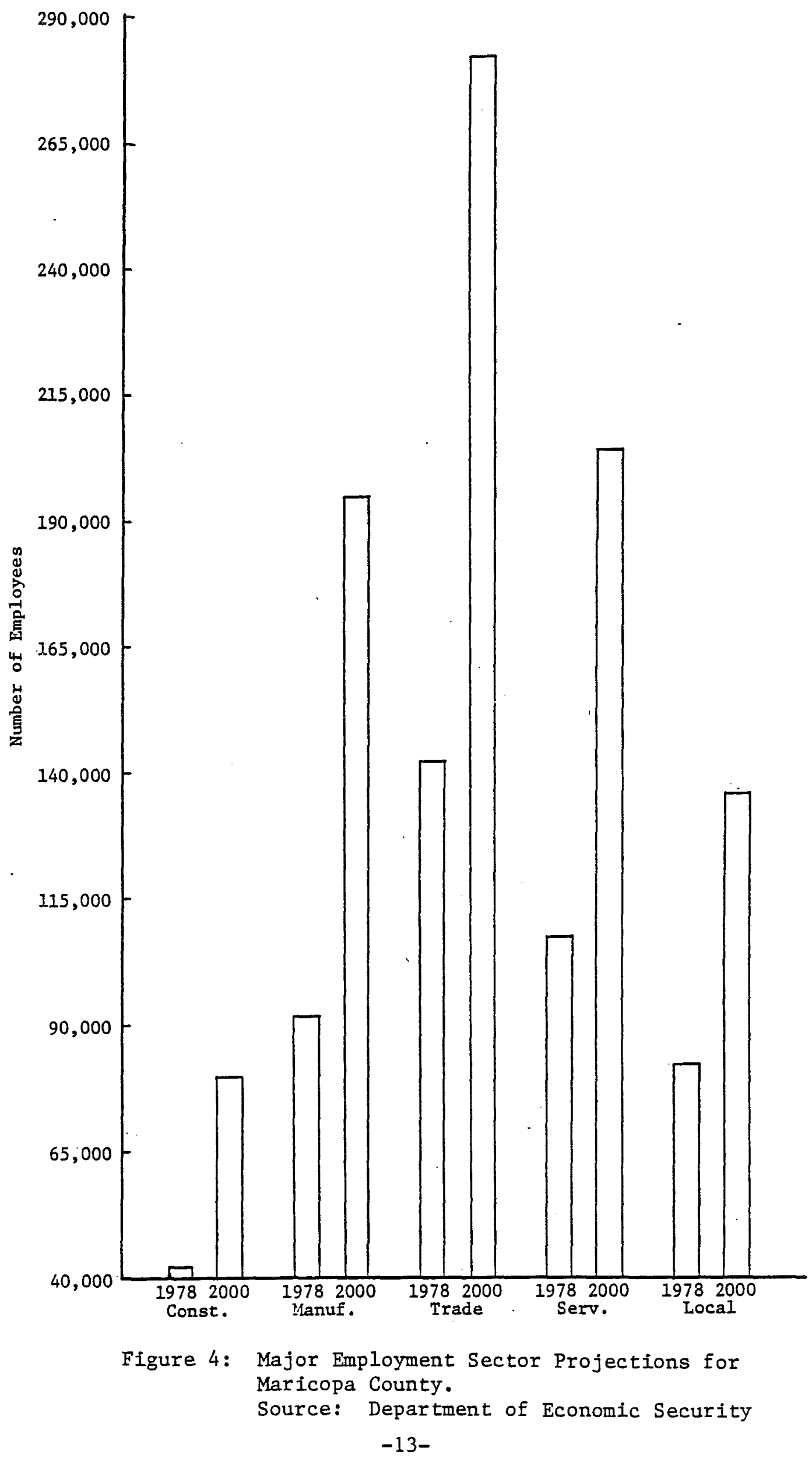




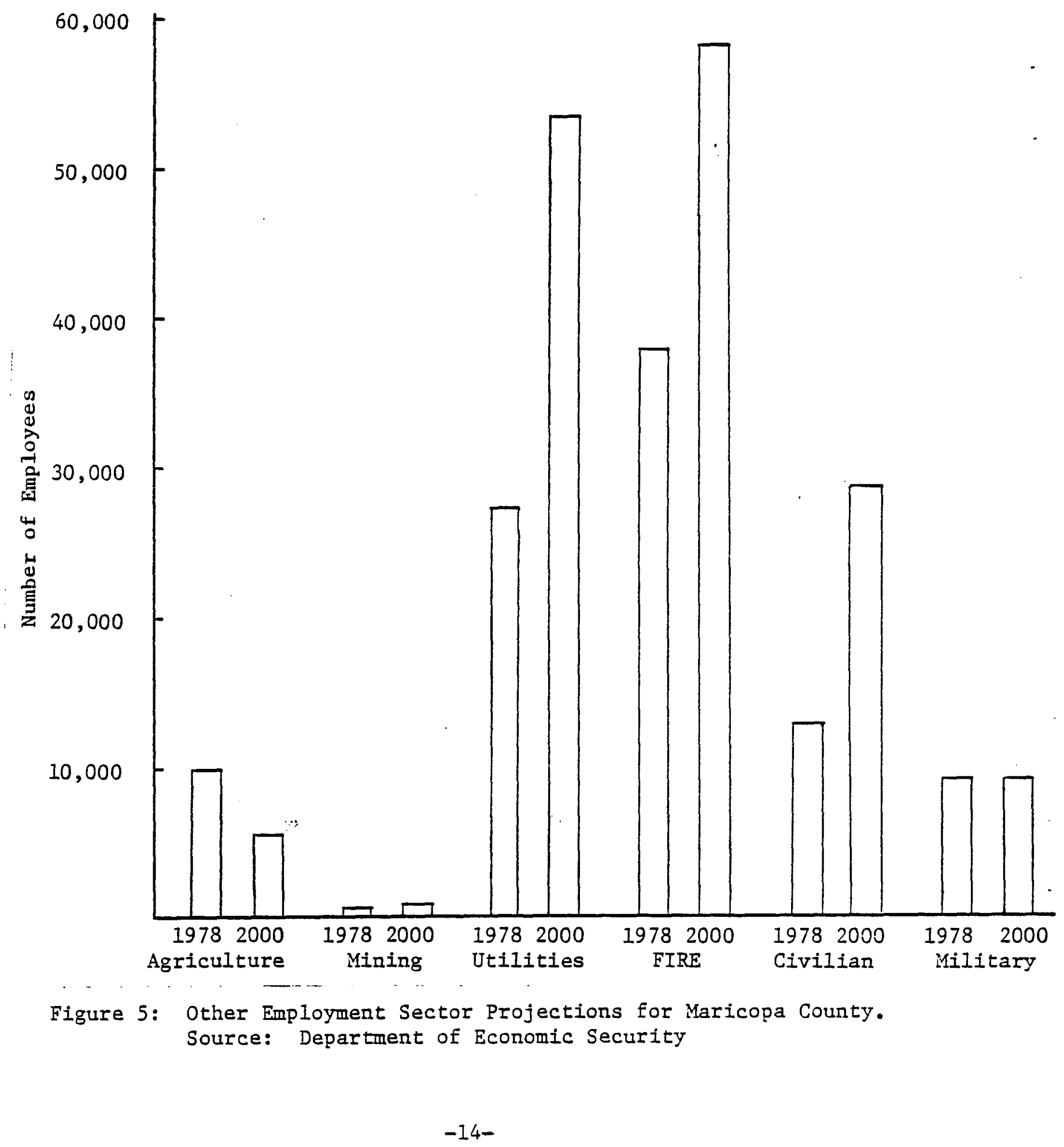




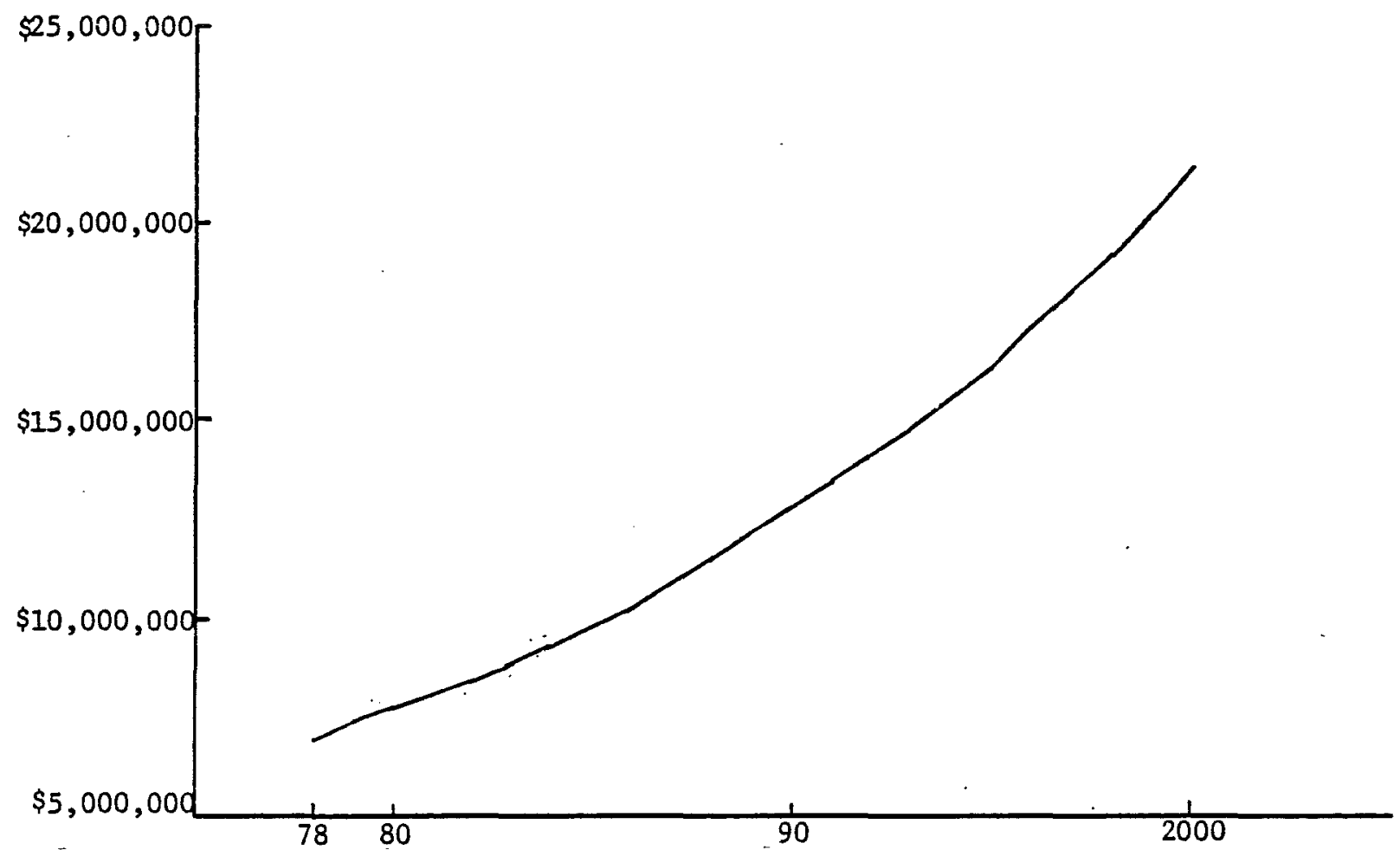

Figure 6: Projections of Personal Income (1972 Dollars) for Maricopa County.

Source: Department of Economic Security

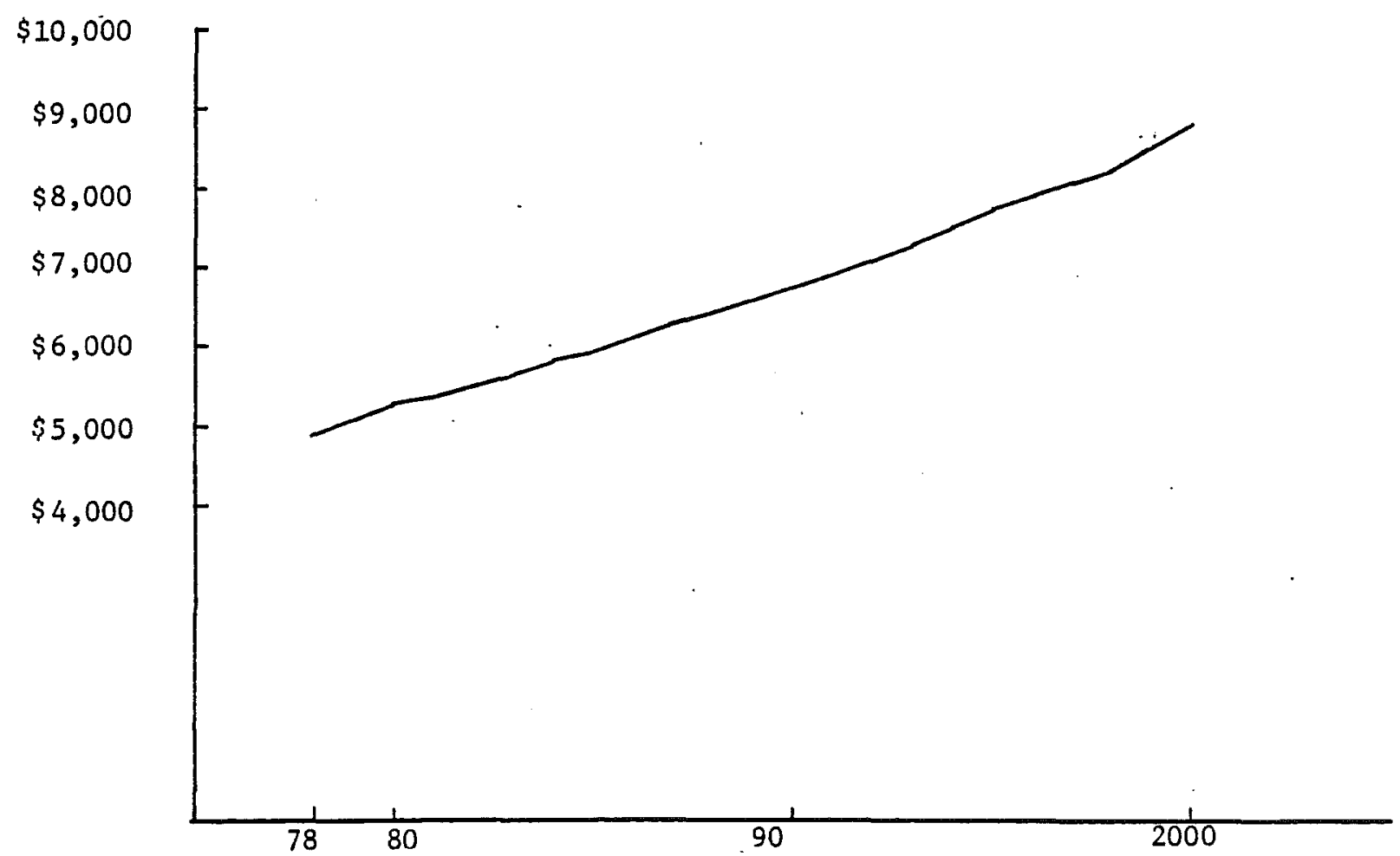

Figure 7: Projections of Personal Per Capita Income (1972 Dollars) for Maricopa County.

Source: Department of Economic Security

$-15-$ 
the economy. One of these is retail sales figures. Between 1968 and 1978, retail sales in Maricopa County showed a total increase of 263.7 percent. Bank deposits are also an indication of economic well being and stability. Between 1968 and 1978, there was a 214.9 percent increase in bank deposits. Growth in both retail sales figures and bank deposits is an indication of a strengthened economy.

In summary, Maricopa County as a whole, especially Phoenix, is one of the fastest growing areas in the state in terms of both industrial growth and population. Such facts encourage and anticipate a successful introduction of geothermal energy for various applications such as providing heat for industrial processes, assisting agriculture and food processing and heating and cooling comercial buildings and private residences. Geothermal energy could provide a substantial input of energy to Maricopa County which would aid in meeting its energy needs in the future. LAND OWNERSHIP

Figure 8 shows a general land ownership map for Maricopa County, divided between Federal, State, City, County, Indian and Private Lands. Percentages of land are shown in Table 5. Procedures for acquiring surface and mineral rights vary depending upon which sector owns the land.

TABLE 5: LAND OWNERSHIP IN MARICOPA COUNTY

\begin{tabular}{lrc}
\hline Sector & Percentage & Total Acres \\
\hline Private & 27 & $1,594,253$ \\
City \& County & 2 & 118,093 \\
State & 10 & 590,464 \\
Indian & 4 & 236,186 \\
Federal & 57 & $3,365,645$ \\
Source: & Arizona Water Commission (1977) & \\
\hline
\end{tabular}




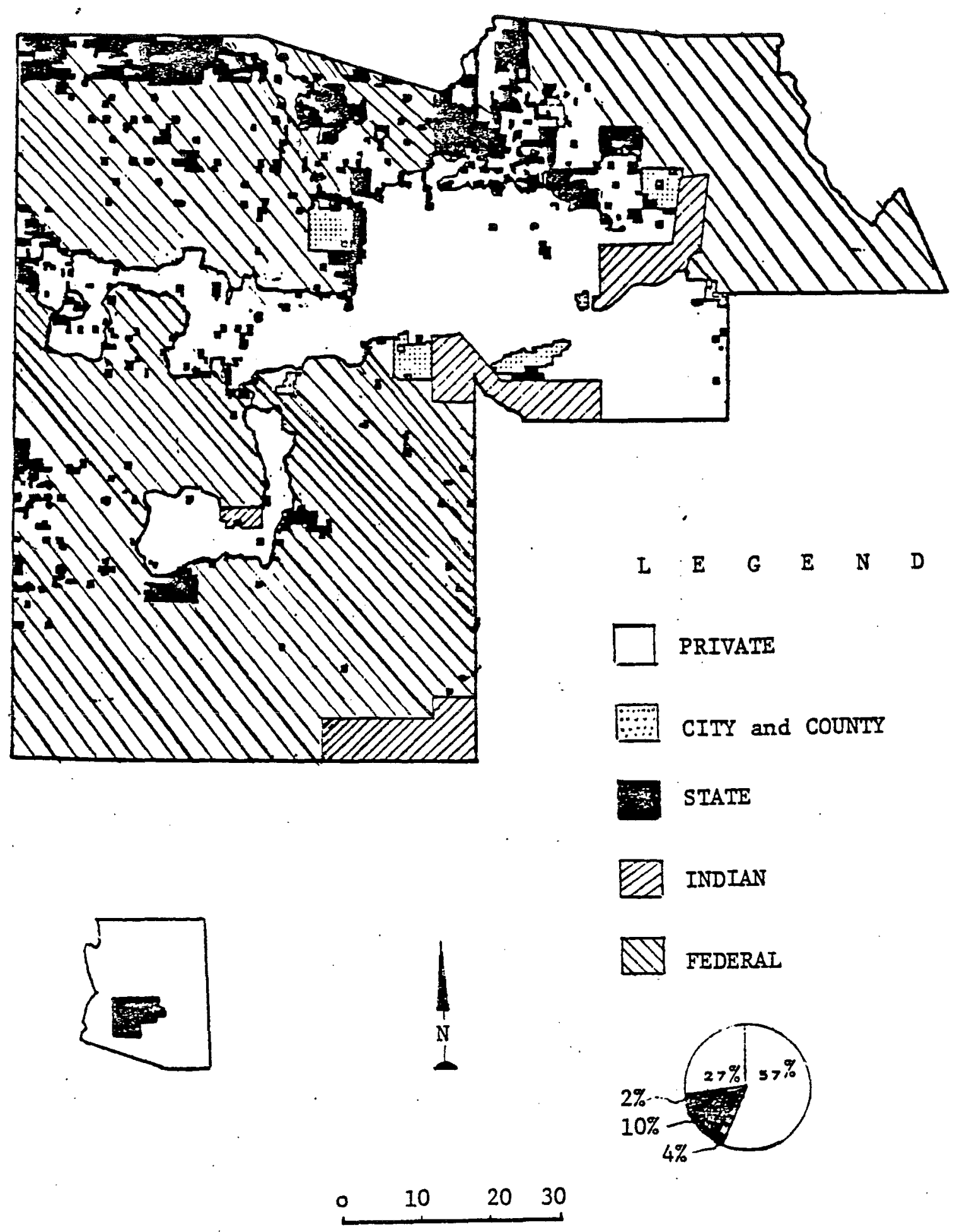

Figure 8: General Land Ownership Map for Maricopa County.
Source: Arizona Water Commission (1977) 
ENERGY USE

Energy use in Maricopa County by user class is presented in Table 6. An attempt has also been made at projecting energy use for each user class to 2020. The absolute numbers are probably not reflective of what actual consumption will be. However, the general trends in energy use are illustrated. Declines in residential consumption reflect residential consumer responsiveness to price increases and incentives to conserve energy. Also, it is believed that the stock of new homes built over the next 40 years will be 30 to 40 percent more energy efficient than existing homes.

\begin{tabular}{|c|c|c|c|c|c|}
\hline & \multirow{2}{*}{$\begin{array}{l}\text { TABLE 6: MARICOPA } \\
\text { User Class }\end{array}$} & \multicolumn{2}{|c|}{ COUNTY ENERGY-USE } & PROJECTIONS $^{(1)}$ & (Trillion Btu) \\
\hline & & $1978^{(2)}$ & $1985^{(3)}$ & $2000^{(3)}$ & $2020^{(3)}$ \\
\hline & Residential & 34.48 & 31.46 & 27.61 & 30.21 \\
\hline & Commercial & 40.48 & 44.66 & 61.60 & 124.52 \\
\hline & Industrial & 59.33 & 62.89 & 78.69 & 119.37 \\
\hline & Total & 134.29 & 139.01 & 167.90 & 274.10 \\
\hline (1) & $\begin{array}{l}\text { Excludes transporta } \\
\text { generation of elect }\end{array}$ & $\begin{array}{l}\text { tion and col } \\
\text { ricity. }\end{array}$ & version and & transmission 1 & losses from the \\
\hline (2) & $\begin{array}{l}1978 \text { figures for ea } \\
1978 \text { done by the Di } \\
\text { of Arizona. }\end{array}$ & $\begin{array}{l}\text { ch sector } W \\
\text { vision of } E\end{array}$ & $\begin{array}{l}\text { re developed } \\
\text { onomic and } B\end{array}$ & $\begin{array}{l}\text { from Arizona } \\
\text { Business Resear }\end{array}$ & $\begin{array}{l}\text { Energy Use, } \\
\text { rch, University }\end{array}$ \\
\hline (3) & $\begin{array}{l}\text { Projections were de } \\
\text { class, from work do }\end{array}$ & $\begin{array}{l}\text { veloped by } \\
\text { ne by the } N\end{array}$ & $\begin{array}{l}\text { laking use of } \\
\text { W Mexico Ene }\end{array}$ & $\begin{array}{l}\text { growth rates } \\
\text { rgy Institute. }\end{array}$ & for each user \\
\hline
\end{tabular}

Increases in energy use by the commercial and industrial sectors exhibit

less responsiveness to price increases for various types of energy. Energy types considered in this analysis are electricity, natural gas, distillate fuels and liquid petroleum gas. No attempt has been made to pro- 
ject the introduction of solar or other alternative energy sources, nor is their future impact considered. A number of factors determine quantity of energy consumed for each energy type, the two most important being personal income and the price of energy. Since personal income is rising, we can expect consumers of energy to continue to expend money for energy in constant proportions over the years. However, rising prices for natural gas and distillates will cause consumption of these fuels to decline.

Energy Information Administration price increases were used for projecting energy consumption to the year 2020 for all fuel types except electricity. Electricity presents a special case which must be considered separately. Prices for electricity will rise in the 1980 s due to costs incurred in the building of many new plants. In the 1990s when new power plants will no longer be needed, the price of electricity will stabilize since the users will pay only for labor, fuel costs and maintenance. For this reason it is believed that real price growth for electricity will be close to zero over the next 40 years.

Table 7 presents 1979 estimated average energy prices by user class; Table 8 presents a sumary of expected real price increases for each type of energy for the residential, commercial and industrial user classes.

TABLE 7: EST. AVERAGE ENERGY PRICES BY USER CLASS, 1979 (Per Million Btu)

\begin{tabular}{lccc}
\hline & Residential & Commercial & Industrial \\
\hline Electricity & $\$ 13.80-\$ 14.80$ & $\$ 13.60$ & $\$ 8.80^{(1)}-\$ 9.60$ \\
Natural Gas & $\$ 3.03-\$ 3.56$ & $\$ 2.15-\$ 2.83$ & $\$ 1.90$ \\
Liquid Petroleum Gas & $\$ 5.33-\$ 7.16$ & same & same \\
Distillates & $\$ 5.59-\$ 6.19$ & same & same \\
\hline
\end{tabular}

(1) Largest 10 Arizona Public Service Industrial Users

Source: Arizona Public Service, Salt River Project and Retail and Wholesale Energy Companies in Phoenix 
TABLE 8: REAL PRICE GROWTH RATES (By Fuel Type and Consuming Sector)

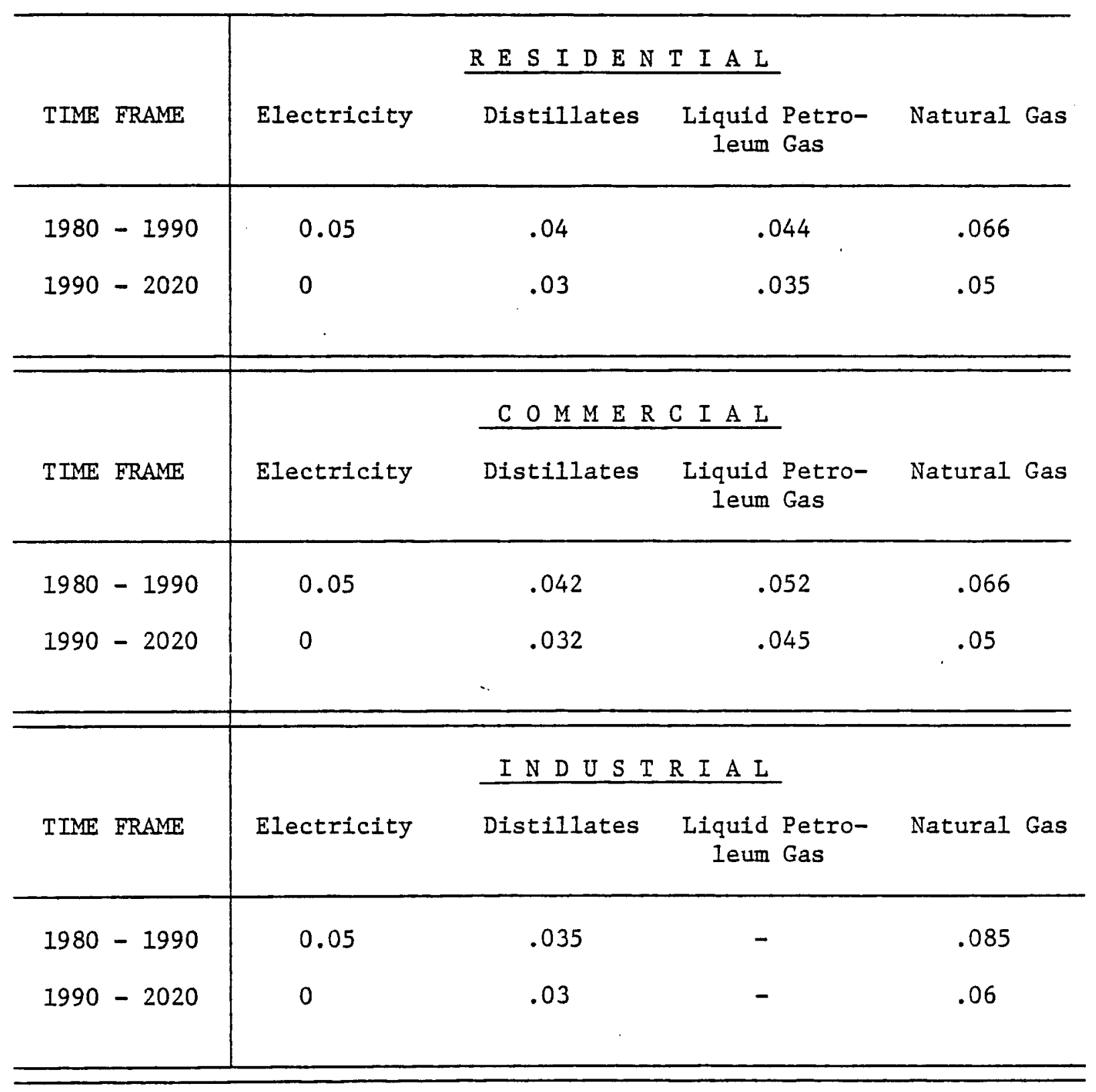

Source: Energy Information Administration (1979) 
Energy-use patterns within Maricopa County are characterized by high demand for electricity during the summer months. Figure 9 illustrates a typical annual load curve for a Phoenix utility. The annual peak in electrical consumption results from the high sumertime demand for space cooling in southern Arizona.

For comparative purposes, Table 9 lists the number of cooling degree and heating degree days for various towns in Maricopa County. Days for which the high temperature is greater than $21^{\circ} \mathrm{C}\left(70^{\circ} \mathrm{F}\right)$ are considered to require cooling. The number of cooling degree days represents a summation of the deviations of daily high temperatures greater than $21^{\circ} \mathrm{C}$ from the defined level of $21^{\circ} \mathrm{C}$. Similarly, days for which the high temperature is less than $21^{\circ} \mathrm{C}$ are considered to require heating, and the number of heating degree days represents a summation of the deviations of the daily high temperatures less than $21^{\circ} \mathrm{C}$ from the defined level of $21^{\circ} \mathrm{C}$. It will be noticed that the cooling degree days is considerably higher than the heating degree days for the towns listed. Thus, the annual peak in electrical consumption that results from the high summertime demand for space cooling is significant. Geothermal space cooling may be able to reduce this annual peak in electrical consumption via direct thermal use or heat pump applications.

In addition to the annual peak is the daily peak. During the summer months, this peak presses near capacity. During a given summer day, electrical loads can range from a low of $900 \mathrm{MW}$ to a high of $2400 \mathrm{MW}$ as air conditioners are turned on. Such fluctuations cause utilities to require additional capacity in order to meet these peak demands. 


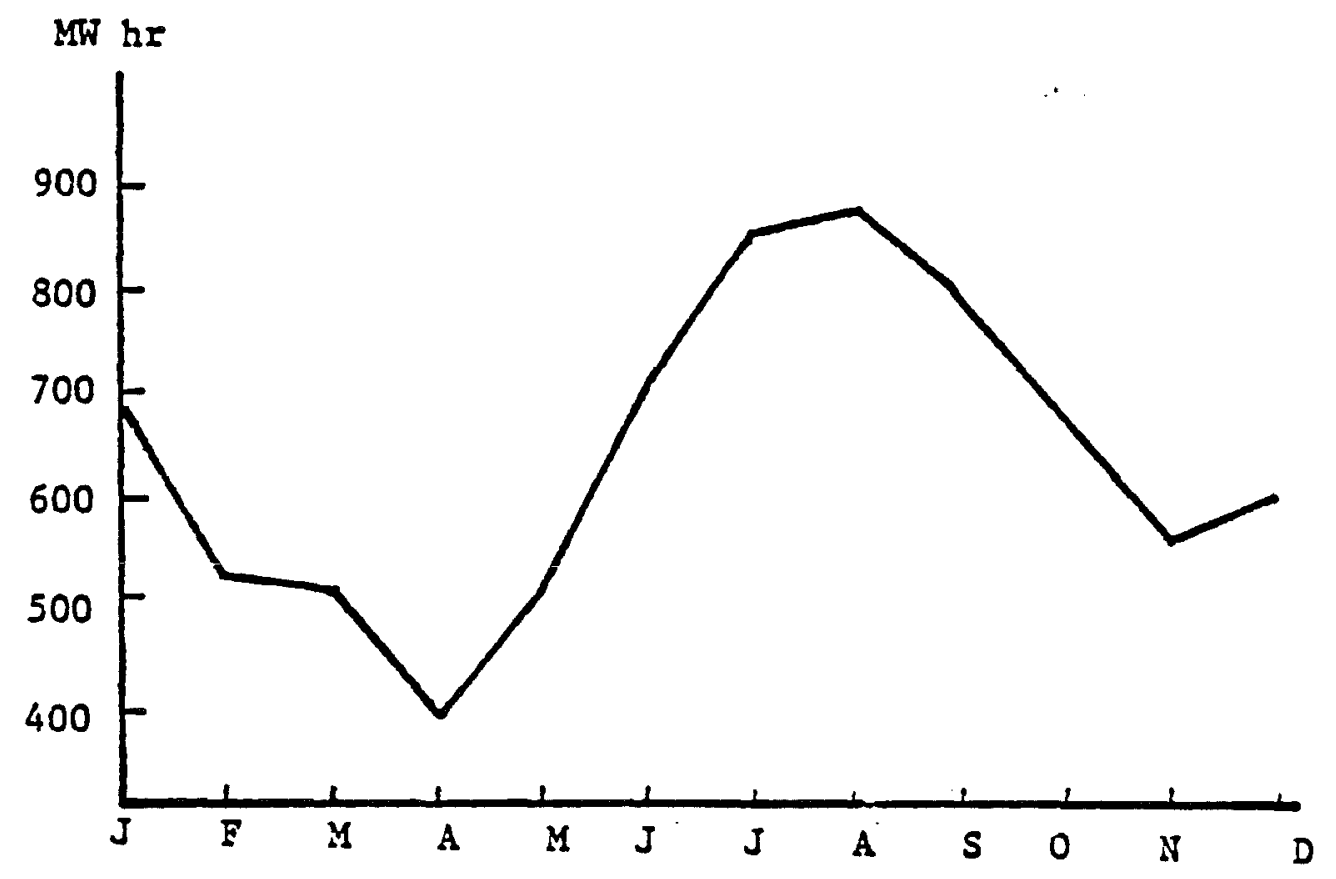

Figure 9: Monthly Electric Power Sales by Salt River Project in Maricopa County (1978).

Source: Salt River Project 
TABLE 9: COOLING AND HEATING DEGREE DAYS FOR SELECTED TOWNS IN MARICOPA COUNTY

\begin{tabular}{lcc}
\hline City & $\begin{array}{c}\text { Cooling } \\
\text { Degree Days }\end{array}$ & $\begin{array}{c}\text { Heating } \\
\text { Degree Days }\end{array}$ \\
\hline Avondale & 3448 & 1550 \\
Buckeye & & 1450 \\
Cashion & & 1500 \\
Cave Creek/Carefree & & 1500 \\
Chandler & 3279 & 1750 \\
El Mirage & & 1750 \\
Gila Bend & 3943 & 1350 \\
Gilbert & & 1700 \\
Glendale & & 1750 \\
Goodyear & 3448 & 1600 \\
Guadalupe & & 1800 \\
Litchfield Park & 3448 & 1550 \\
Mesa & 3173 & 1710 \\
Paradise Valley & & 1800 \\
Peoria & 3062 & 1550 \\
Phoenix & & 1550 \\
Scottsdale & & 1700 \\
Sun City & & 1700 \\
Surprise & & 1750 \\
Tempe & 4343 & 1710 \\
Tolleson & & 1650 \\
Wickenburg & & 2425 \\
Youngstown & & 1750 \\
\hline & & \\
\hline & & 343 \\
\hline
\end{tabular}

Source: National Climatic Center (1978) 
Figure 10 illustrates that the daily peak experienced by Arizona Public Service Company increased each year during the period from 1974 to 1979 . Power companies are required to maintain an additional margin of capacity above the annual peak. Therefore, as the peak grows, additional power plants must be constructed.

In some areas different rates are charged for electric power based on the time of day the electricity is used. Higher rates are associated with electricity used during the day when the power company is operating on more expensive fuel types. This time-of-day pricing is currently in the experimental stage.

WATER

Maricopa County is second only to Yuma County in the availability of a dependable water supply, and the proposed allocations of Central Arizona Project water will increase Maricopa County's supply to more than that of any other county. By 1986, the average dependable supply available is estimated to increase to about 1,452,000 acre-feet per year from the 1979 level of 971,000 acre-feet per year.

Three projections of future water use are presented in Figure 11. The three alternatives take into account the fact that the future level of water use will depend on a variety of factors such as population growth, industrial development and consumer habits and lifestyles. The Alternative Futures provide a range of possibilities which might emerge with changing conditions and attitudes, Each alternative was developed by summing the projections for the following water-using categories: urban, steam electric power, mineral production, irrigated agriculture and fish and wildife. Under Alternative I, water use is generally high while under Alternative II, 


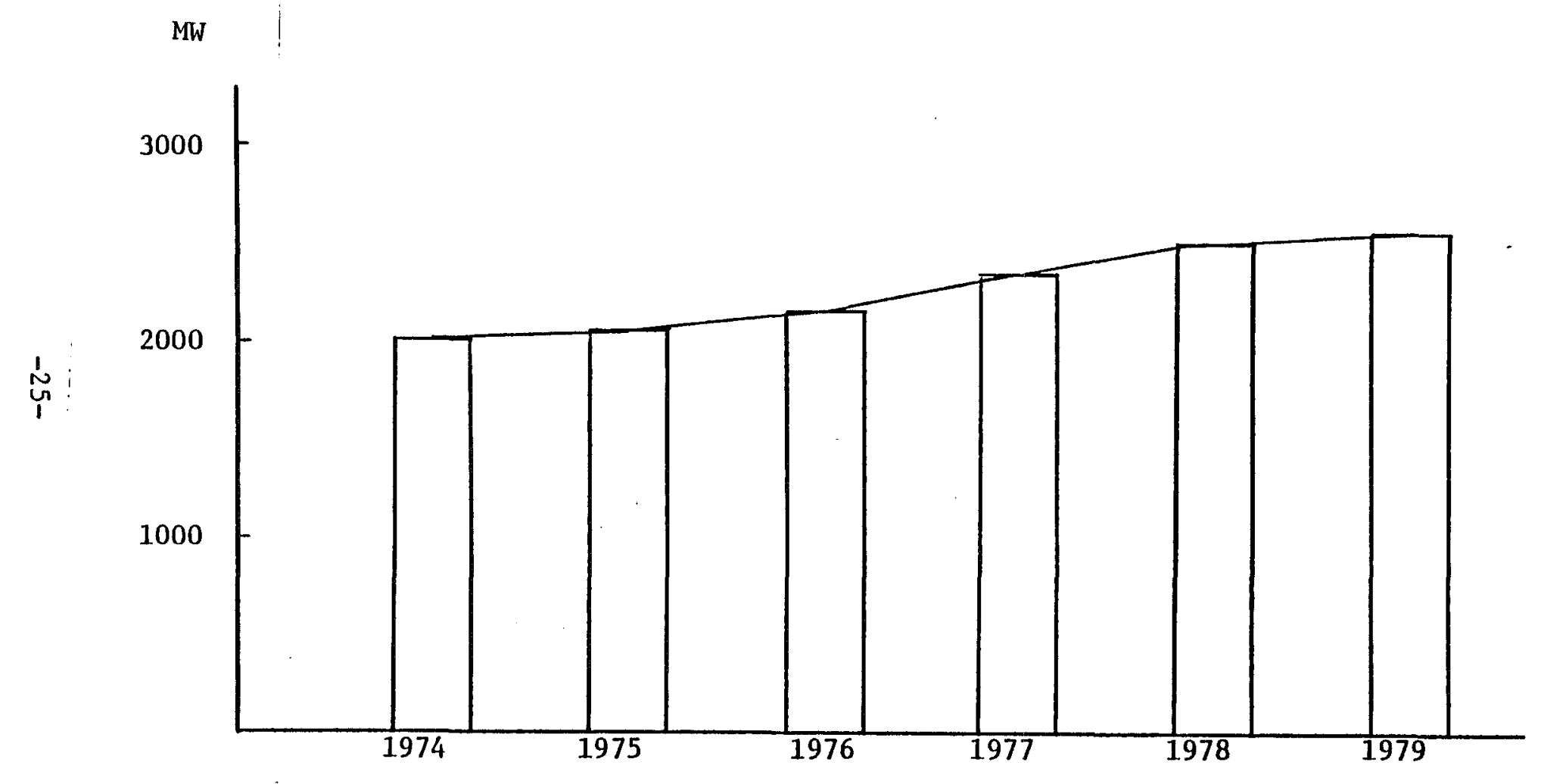

Figure 10: Growth in the Daily Electrical Peak. Source: Arizona Public Service Co. 


\section{PROJECTED ALTERNATIVE WATER DEPLETIONS \\ AND DEPENDABLE SUPPLY}

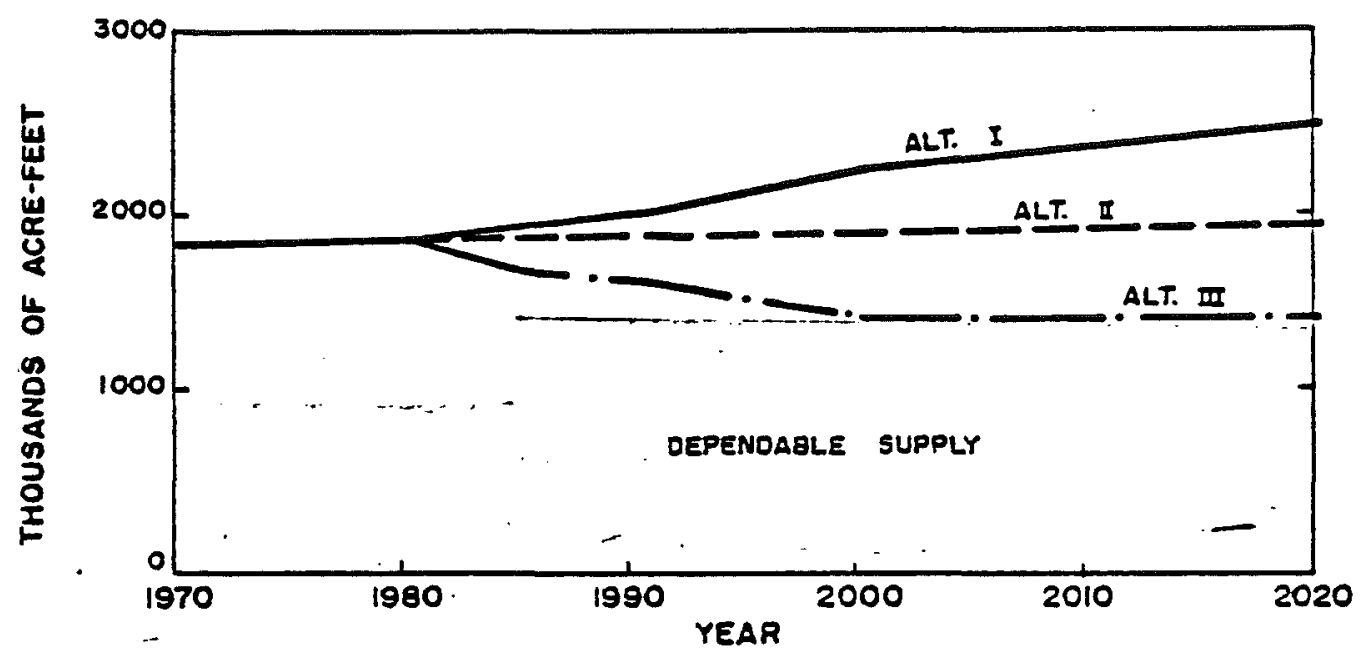

\section{ALTERNATIVE FUTURES SUMMARY}

\begin{tabular}{|c|c|c|c|c|c|c|c|}
\hline \multirow{3}{*}{$\begin{array}{c}\text { TTEM } \\
\text { (Qumatties in Thousands) }\end{array}$} & \multirow[b]{3}{*}{1970} & \multicolumn{3}{|c|}{ MLTERNATIVE } & & \multicolumn{2}{|c|}{ FUTURES } \\
\hline & & \multicolumn{2}{|c|}{$\mathbf{I}$} & \multicolumn{2}{|c|}{ iI } & \multicolumn{2}{|c|}{ III } \\
\hline & & 1990 & 2020 & 1990 & 2020 & 1990 & 2020 \\
\hline POPULATION & 969.0 & 2350.0 & 4670.0 & 1920.0 & 3180.0 & 1920.0 & 3180.0 \\
\hline HARVESTED ACAES & 470.0 & 4180 & 382.0 & 4120 & 332.0 & 342.0 & 184.0 \\
\hline UREAN DEPLETIONS AFMR & 183.0 & 330.0 & 58,0 & 331.0 & 478.0 & 331.0 & 478.0 \\
\hline STEAM ELECTRIC OEPLETIONS AF/YA & 7.8 & 107.0 & 534.0 & 77.5 & 279.0 & 7.5 & 279.0 \\
\hline MINERAL DEPLETIONS AF/YR & 1.0 & 3.0 & 5.0 & 30 & 5.0 & 30 & 5.0 \\
\hline AGRICULTURAL DEPL AFTA & 1681.0 & 1480.0 & 1310.0 & 1480.0 & 1140.0 & 1210.0 & 633.0 \\
\hline TOTAL WATER OEPL AF/YA' & 1873 & $19 \pi$ & 2494 & 1879 & 1909 & 1629 & 1402 \\
\hline DEPENOABLE WATEA AF/YA & 971 & 1452 & 1402 & 1452 & 1402 & 1452 & 1402 \\
\hline SURPLUS SUPPLY (Dof.) & (902) & (525) & (1092) & $(427)$ & $(507)$ & $(177)$ & 0 \\
\hline
\end{tabular}

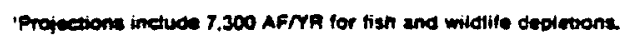

Figure 11: Projected Alternatives for Water Use in Maricopa County. Source: Arizona Water Commission (1977) 
water use is intermediate for all user categories. Under Alternative III, water use is intermediate for all user categories except irrigated agriculture for which water use is low.

Comparison of future water supplies and uses shows that depletion will be 1.8 times greater than dependable supplies. The total water depletion is about 2.5 million acre-feet per year, over 50 percent of which is used for irrigated agriculture. However, as a result of Central Arizona Project deliveries, the water supply deficiency is projected to be reduced from a 1970 level of 902,000 to 427,000 acre-feet per year in 1990 and 507,000 acre-feet per year in 2020. Agricultural depletions would represent about 45 percent of the total in the year 2020 .

Electric power generation in Maricopa County is projected to increase substantially in the future. The scheduled completion of the Palo Verde Nuclear Generating Station west of Phoenix will contribute to the county's water use through requirements for cooling water for the nuclear power plants. Thus, Maricopa County will become the largest user of water in Arizona. MATCHING GEOTHERMAL RESOURCES TO POTENTIAL USERS

The final aim of this Area Development Plan is to match potential users of geothermal energy to potential resources. The limited amount of resource information for Maricopa County suggests that $110^{\circ} \mathrm{C}\left(230^{\circ} \mathrm{F}\right)$ might be a reasonable estimate of the average reservoir temperature. Therefore, potential uses for geothermal energy are restricted to those uses whose heat requirements are less than $110^{\circ} \mathrm{C}\left(230^{\circ} \mathrm{F}\right)$. In addition, an attempt is made to define a time frame in which geothermal resources will realize commercial use. It was with the assistance of the New Mexico Energy Institute (NMEI) that this time line was produced. Therefore, matches found within the industrial, 
commercial and agricultural sectors are considered. The residential sector was not included as a potential user class since modeling to date has concentrated on space heating only. Because space heating is not a significant part of the energy demand within Maricopa County, general results of the model have been omitted. However, results of specific space heating analyses are presented for Goodyear, Avondale and Litchfield Park.

Goodyear and Avondale are two communities located 16 miles west of Phoenix. The two cities, located beside each other, have combined populations of approximately 11,000 people. Both communities will grow at a compound annual rate of 10-20 percent through the year 2000. Clearly, both areas exhibit high growth potential for the future.

New growth in Goodyear and Avondale over the next twenty years will present many situations for geothermal development. Geothermal development will be most economic for new growth situations rather than for retrofit situations. In addition, the existence of low temperature geothermal resources is quite evident in the area. To date, over 30 existing wells in the area exhibit either temperatures greater than $50^{\circ} \mathrm{C}\left(122^{\circ} \mathrm{F}\right)$ or have calculated temperature gradients greater than $50^{\circ} \mathrm{C} / \mathrm{km}\left(3.7^{\circ} \mathrm{F} / 100 \mathrm{ft}.\right)$ Three of these wells have discharge temperatures of $50^{\circ} \mathrm{C}\left(122^{\circ} \mathrm{F}\right)$ with flow rates greater than $22701 / \mathrm{min}$ (600 gpm) at depths less than $500 \mathrm{~m}$ (1640 ft.)

The analysis which follows assumes that a private developer would be able to get the rights to one of the wells currently flowing at $50^{\circ} \mathrm{C}\left(122^{\circ} \mathrm{F}\right)$. The developer would then construct a new comnercial facility, possibly a shopping plaza or a mall, at the well site. The developer would use the existing geothermal well to provide heat and hot water for the shopping center. Heat demand for the building was calculated based on a average building heating load 
of $33.3 \mathrm{Btu} / \mathrm{hr} / \mathrm{ft}^{2}$.

For purposes of this analysis, two building sizes were chosen in order to measure the effect of size on the economics of such a project. It was assumed that one building would be $55,000 \mathrm{ft}^{2}$ and the second building would be $280,000 \mathrm{ft}^{2}$. The peak heat demand would be $1,830,000 \mathrm{Btu} / \mathrm{hr}$ for the smaller facility and 9,250,000 Btu/hr for the larger facility. As will become clear, size is a critical factor in making a geothermal heating project economic.

For the two different-sized facilities, all other assumptions necessary for the analysis were held constant. Those necessary assumptions are sumarized in Table 10.

Using the outlined assumptions in the table (plus others), a life-cycle cost for the geothermal energy was calculated and compared to the price of natural gas. For the smaller facility, the price of geothermal energy per milion Bti was found to be $\$ 4.94$, which given an increasing price for natural gas would be competitive in 1993. For the larger facility, the price of geothermal energy was calculated at $\$ 2.55$ per million Btu, implying that it would be comparable in price to natural gas today. Net savings over the life of the projects would be $\$ 12,000$ for the smaller facility and $\$ 262,000$ for the larger facility. Table 11 presents an itemized cost summary for the two facilities. In addition to capital costs there are also operating costs which include maintenance and electricity to run the pumps and fans for the system. These costs are assumed to be 2.5 percent of the cumulative investment per year. Operating costs are not a separate line item. Rather they are reflected in the final price per million Btu. Further, for each case considered, the developer receives a 20 percent real rate of return for each of the first 15 years of the project and a 12 percent real return after that: 
Table 10: ASSUMPTIONS FOR GEOTHERMAL HEATING FOR COMMERCIAL BUILDINGS

Variable

Resource Temperature

Depth

Well Status

Flow Rate

Industrial Heat Demand

Bond Rate (above inflation)

Equity Capital

Sales Tax Rate

State Income Tax Rate

Natural Gas Price (per MBtu)

Real Fuel Price Increase per year to 1990

Real Fuel Price Increase per year beyond 1990

Project Life

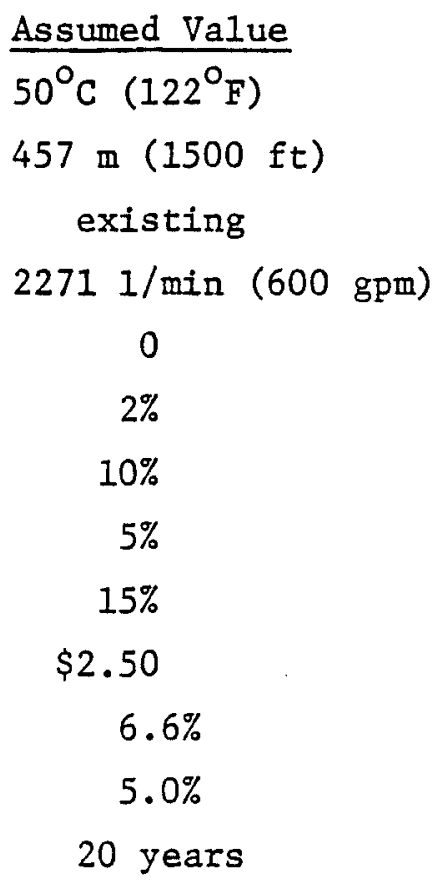

Table 11: COST COIPARISON AND SUMMARY

Geothermal Space Heating for Commercial Facilities - Goodyear/Avondale

\begin{tabular}{|c|c|c|}
\hline Category & $\begin{array}{l}\text { Present } \mathrm{Va} \\
280,000 \mathrm{ft}^{2} \\
\end{array}$ & $\begin{array}{l}\text { ital Costs } \\
55,000 \mathrm{ft}^{2}\end{array}$ \\
\hline Design & $\$ 19,007$ & $\$ 4,306$ \\
\hline We11s* & 25,939 & 18,715 \\
\hline Commercial Conversion & 108,324 & 17,130 \\
\hline Heat Exchangers & 63,356 & 11,236 \\
\hline TOTALS & $\$ 216,626$ & $\$ 51,387$ \\
\hline $\begin{array}{l}\text { *Well cost includes co } \\
\text { In this case, drillin }\end{array}$ & $\begin{array}{l}\text { for pumps an } \\
\text { not require }\end{array}$ & payments. \\
\hline
\end{tabular}

Although these data are most useful in comparing the relative savings from using geothermal in two different-sizedbuildings, they also indicate that using 
existing geothermal wells is an economic alternative to other conventional energy sources for providing space heating and hot water. It is also clear that size plays a significant role in determining the economic savings possible from utilizing geothermal energy. With future growth anticipated for the Goodyear/Avondale area of Maricopa County, the use of geothermal energy could aid in reducing future energy costs.

Litchfield Park is another community located in Maricopa County, approximately 16 miles west of Phoenix and north of Goodyear and Avondale. Litchfield Park has evolved as a planned community with emphasis on development of self-sufficient villages having their own stores, post offices, businesses and recreational facilities. The 1980 population of Litchfield Park was estimated to be 3,500 people. From 1970 to 1980, Litchfield Park grew at an annual compound rate of 7.5 percent and future projections suggest the trend will continue to the year 2000 .

The previous analysis of a commercial facility in Goodyear or Avondale would also be applicable to Litchfield Park. As was the case in Goodyear and Avondale, Litchfield Park is also located in an area where numerous warm wells are known to exist. One of these known wells has a discharge temperature greater than $50^{\circ} \mathrm{C}\left(122^{\circ} \mathrm{F}\right)$ with a flow rate of $43901 /$ min $(1160 \mathrm{gpm})$ at a depth of $600 \mathrm{~m}(1970 \mathrm{ft})$.

As was the case with the previous analysis, it is assumed that a developer could acquire the rights to such a well. In this case it is further assumed that the developer is interested in building residential housing and in using geothermal energy to provide heating and hot water for the complex. All other assumptions were held constant. 
For this analysis, two development types are considered, The first consists of 500 apartments capable of housing 1500 people and the second consists of 375 houses and 125 apartments capable of housing 1500 people. In both cases, no commercial or industrial energy users are considered. Design of the heating system was hased on average heating values for homes and apartments depending on outside temperature. Heat demand for the apartments was assumed to be $300 \mathrm{Btu} / \mathrm{hr} / \Delta^{\circ} \mathrm{F}$. Litchfield Park has an average outside low temperature of $2^{\circ} \mathrm{C}\left(35^{\circ} \mathrm{F}\right)$. Peak heating loads are calculated to be $10,800 \mathrm{Btu} / \mathrm{hr}$ for the apartments and $27,000 \mathrm{Btu} / \mathrm{hr}$ for the homes. Total peak demand for the 500 apartments is $5,400,000 \mathrm{Btu} / \mathrm{hr}$ and combined total peak demand for homes and apartments is $11,475,000 \mathrm{Btu} / \mathrm{hr}$. Under the assumptions listed in Table 12, a life-cycle cost for geothermal was calculated and compared to the current price of natural gas. For the development consisting of all apartments, the price of geothermal' energy was found to be $\$ 3.48$ per MBtu, which would make geothermal energy the least cost energy alternative in 1984. For the development consisting of both homes and apartments, the geothermal price was $\$ 4.80$ per MBtu and was economic in 1989. Net fuel cost savings over the life of the two projects would be $\$ 1,808,000$ for the apartment complex and $\$ 1,115,000$ for the combined development. Table 13 presents an itemized cost summary for the two developments. 
Table 12: ASSUMPTIONS FOR RESIDENTIAL GEOTHERMAL HEATING

\begin{tabular}{lc} 
Variable & $\begin{array}{c}\text { Assumed Value } \\
\text { Resource Temperature }\end{array}$ \\
Depth & $50^{\circ} \mathrm{C}\left(122^{\circ} \mathrm{F}\right)$ \\
Well Status & 600 m (1970 ft) \\
Flow Rate & existing \\
Industrial Heat Demand & 4390 min (1160 gpm) \\
Commercial Heat Demand & 0 \\
Well Distance & 0 \\
Bond Rate (above inflation) & 1 mile \\
Equity Capital & $2 \%$ \\
Sales Tax Rate & $10 \%$ \\
State Income Tax Rate & $5 \%$ \\
Natural Gas Price (per MBtu) & $15 \%$ \\
Real Fuel Price Increase Per Year to 1990 & $\$ 3.25$ \\
Real Fuel Price Increase Per Year, 1990-2000 & $6.6 \%$ \\
Project Life & $5.0 \%$ \\
\hline
\end{tabular}

Table 13: COST COMPARISON AND SUMMARY

Geothermal Space Heating for the Residential Sector - Litchfield Park

\begin{tabular}{lcc}
\hline & \multicolumn{2}{c}{ Present Value of Capital Costs } \\
Category & Apartment Complex & Houses and Apartments \\
Design & $\$ 150,880$ & $\$ 199,114$ \\
Wells* & 25,939 & 22,125 \\
Transmission & 136,516 & 139,968 \\
Heat Exchangers & 59,117 & 71,093 \\
Central System & $1,294,782$ & $1,763,643$ \\
TOTALS & $\$ 1,667,234$ & $\$ 2,195,943$ \\
*Well costs include leasing and pump costs. Well was assumed to exist.
\end{tabular}


In addition to capital costs there are also operating costs which include maintenance and electricity costs to run the pumps and fans for the system. These costs are assumed to be 2.5 percent of the cumulative investment per year. Operating costs are not a separate line item. Rather they are reflected in the final price per million Btu. Further, for each case considered the developer receives a 20 percent real return on investment for each of the first 15 years of the project and a 12 percent real return after that.

A point worth noting is that the amount of flow available exceeds the flow rate required to meet the peak demand. For the all-apartment complex only $10701 /$ min $(282 \mathrm{gpm})$ are required, leaving 75 percent of the flow unused. Expanding the system to include 2000 apartments would improve the economics of the system. Similarly, the combined complex of houses and apartments requires $22861 /$ min (604 gpm), leaving 48 percent of the heat energy available for use. Expansion of this system would also improve the system economics. A second comment regarding the significant cost factors also seems appropriate. Based on local well-drilling costs, if the developer had to drill a well, the final price per million Btu for the all-apartment complex would only increase to $\$ 3.81 / \mathrm{MB} t u$, an increase of 9.6 percent. It is clear that the cost of a single well (excluding reinjection wells) would not seriously affect the final price of geothermal energy. Rather, the most significant cost factor is the distribution system necessary to deliver the heat. Because a smaller and less extensive distribution system is required, the overall system economics appear more favorable for the apartment complex. The remaining part of this section attempts to match potential users to geothermal resources. One approach concentrated on the industrial 
sector within Maricopa County. With the use of information from the Solar Energy Research Institute, industries having process heat requirements of less than $110^{\circ} \mathrm{C}\left(230^{\circ} \mathrm{F}\right)$ were identified within Maricopa County. Annual energy consumption was then estimated for each of these industries based upon the number of workers which they employ. These industries, classified by four-digit SIC codes, appear in Table 14 along with their estimated annual energy consumption. This information was used to model the introduction of geothermal energy into the process heat market.

The model is described in Appendix A. Time line results of the modeling are presented in Figure 12 and 13 for private development and city development, respectively. The results indicate that geothermal energy for process heat would come on line much faster under city development than under private development. The differences are due to differing costs of capital, rates of return and tax liabilities for the two types of development. For comparison, the results of the modeling are presented in Table 15 in terms of barrels of oil replaced by geothermal energy. Under both types of development, the use of geothermal energy could save a significant amount of oil by 1985 with even more oil being replaced by geothermal energy in 1990 and beyond.

TABLE 15: BARRELS OF OIL REPLACED BY GEOTHERMAL ENERGY PER YEAR Process Heat Market

\begin{tabular}{lcccc}
\hline & 1985 & 1990 & 2000 & 2020 \\
\hline Private Developer & 133,930 & $4,357,143$ & $5,696,430$ & $6,696,430$ \\
City Utility & $4,357,143$ & $5,035,714$ & $6,035,714$ & $6,696,430$ \\
\hline
\end{tabular}


TABLE 14: ESTIMATED PROCESS HEAT ENERGY REQUIREMENTS

FOR SELECTED INDUSTRIES IN MARICOPA COUNTY

Assumed Reservoir Temperature: $110^{\circ} \mathrm{C}\left(230^{\circ} \mathrm{F}\right)$

\begin{tabular}{|c|c|c|c|}
\hline SIC Code & $\begin{array}{l}\text { Number } \\
\text { of Firms }\end{array}$ & Description & $\begin{array}{l}\text { Energy Use } \\
\text { Btu/yr } \times 10^{9}\end{array}$ \\
\hline 2016 & 4 & Poultry Dressing & 6.16 \\
\hline 2021 & 1 & Creamery Butter & 87.9 \\
\hline 2024 & 13 & Ice Cream/Frozen Desserts & 265.9 \\
\hline 2026 & 8 & Fluid Milk & 86.85 \\
\hline 2063 & 1 & Beet Sugar & 208.0 \\
\hline 2065 & 1 & Candy/Confections & 1.3 \\
\hline 2074 & 2 & Cottonseed Oil Mills & 135 \\
\hline 2077 & 4 & Animal and Marine Fats and $0 i l$ & 136.8 \\
\hline 2086 & 11 & Soft Drinks & 588.2 \\
\hline 2097 & 4 & Ice & 31.2 \\
\hline 2421 & 4 & Saw Mills & 44.9 \\
\hline 2431 & 33 & Millwork & 201.0 \\
\hline 2441 & 4 & Wood Boxes & 18.7 \\
\hline 2491 & 2 & Wood Preserving & 8.2 \\
\hline 2499 & 5 & Misc. Wood Products & 14.2 \\
\hline 2511 & 26 & Wood Furniture & 147.6 \\
\hline 2512 & 8 & Wood Furniture w/Upholstery & 11.85 \\
\hline 2515 & 16 & Mattresses & 36.7 \\
\hline 2519 & 1 & Misc. Furniture & 0.3 \\
\hline 2521 & 1 & Wood Office Furniture & 0.5 \\
\hline 2541 & 9 & Wood Partitions & 49.7 \\
\hline 2542 & 2 & Metal Partitions & 14.8 \\
\hline 2591 & 4 & Drapery Hardware & 4.0 \\
\hline 2599 & 3 & Misc. Furniture & 6.3 \\
\hline 2822 & 1 & Synthetic Rubber & 77.6 \\
\hline 2951 & 1 & Paving Mixtures and Blocks & 2693.7 \\
\hline 3111 & 1 & Leather Processing & 13.5 \\
\hline 3161 & 1 & Luggage & 0.3 \\
\hline 3171 & 1 & Handbags & 0.2 \\
\hline 3172 & 2 & $\begin{array}{l}\text { Personal Leather Goods } \\
-36-\end{array}$ & 38.9 \\
\hline
\end{tabular}


Table 14, continued

\begin{tabular}{|c|c|c|c|}
\hline SIC Code & $\begin{array}{l}\text { Number } \\
\text { of Firms }\end{array}$ & Description & $\begin{array}{l}\text { Energy Use } \\
\text { Btu/yr } \times 10^{9}\end{array}$ \\
\hline 3199 & 2 & Miscellaneous Leather Goods & 1.5 \\
\hline 3273 & 22 & Ready-Mix Concrete & 234.2 \\
\hline 3281 & 19 & Cut Stone Products & 8.06 \\
\hline 3411 & 4 & Metal Cans & 44.2 \\
\hline 3423 & 4 & Hand Tools & 7.3 \\
\hline 3429 & 9 & Miscellaneous Hardware & 93.7 \\
\hline 3431 & 1 & Enameled Iron Plumbing & 6.7 \\
\hline 3432 & 1 & Brass Plumbing & 4.0 \\
\hline 3433 & 3 & Fuel Heaters & 6.2 \\
\hline 3441 & 30 & Structural Metal & 132.2 \\
\hline 3442 & 8 & Metal Doors & 47.9 \\
\hline 3443 & 5 & Boiler Shops & 18.3 \\
\hline 3444 & 38 & Sheet Metal Work & 441.6 \\
\hline 3449 & 8 & Miscellaneous Metal Work & 70.8 \\
\hline 3451 & 11 & Screw Machines & 26.54 \\
\hline 3452 & 3 & Nuts/Bolts/Screws & 32.7 \\
\hline 3471 & 11 & Metal Plating & 113.8 \\
\hline 3479 & 5 & Misc. Metal Surface Treatment & 66.57 \\
\hline 3496 & 9 & Miscellaneous Fabricated Wire Products & 2.3 \\
\hline 3499 & 13 & Miscellaneous Metal Products & 68.59 \\
\hline 3519 & 3 & Internal Combustion Eng. & 14.1 \\
\hline 3713 & 4 & Trucks/Bus & 14.7 \\
\hline 3751 & 2 & Truck Trailers & 2.6 \\
\hline 3811 & 7 & Engineering Instruments & 28.54 \\
\hline 3851 & 4 & Opthalmic Goods & 6.57 \\
\hline 3949 & 10 & Sporting Goods & 79.62 \\
\hline 3953 & 2 & Marking Devices & 2.1 \\
\hline 3961 & 1 & Costume Jewelry & 0.5 \\
\hline 3962 & 1 & Artificial Plants & 0.3 \\
\hline 3999 & 16 & Miscellaneous Manufactured Products & 27.74 \\
\hline
\end{tabular}




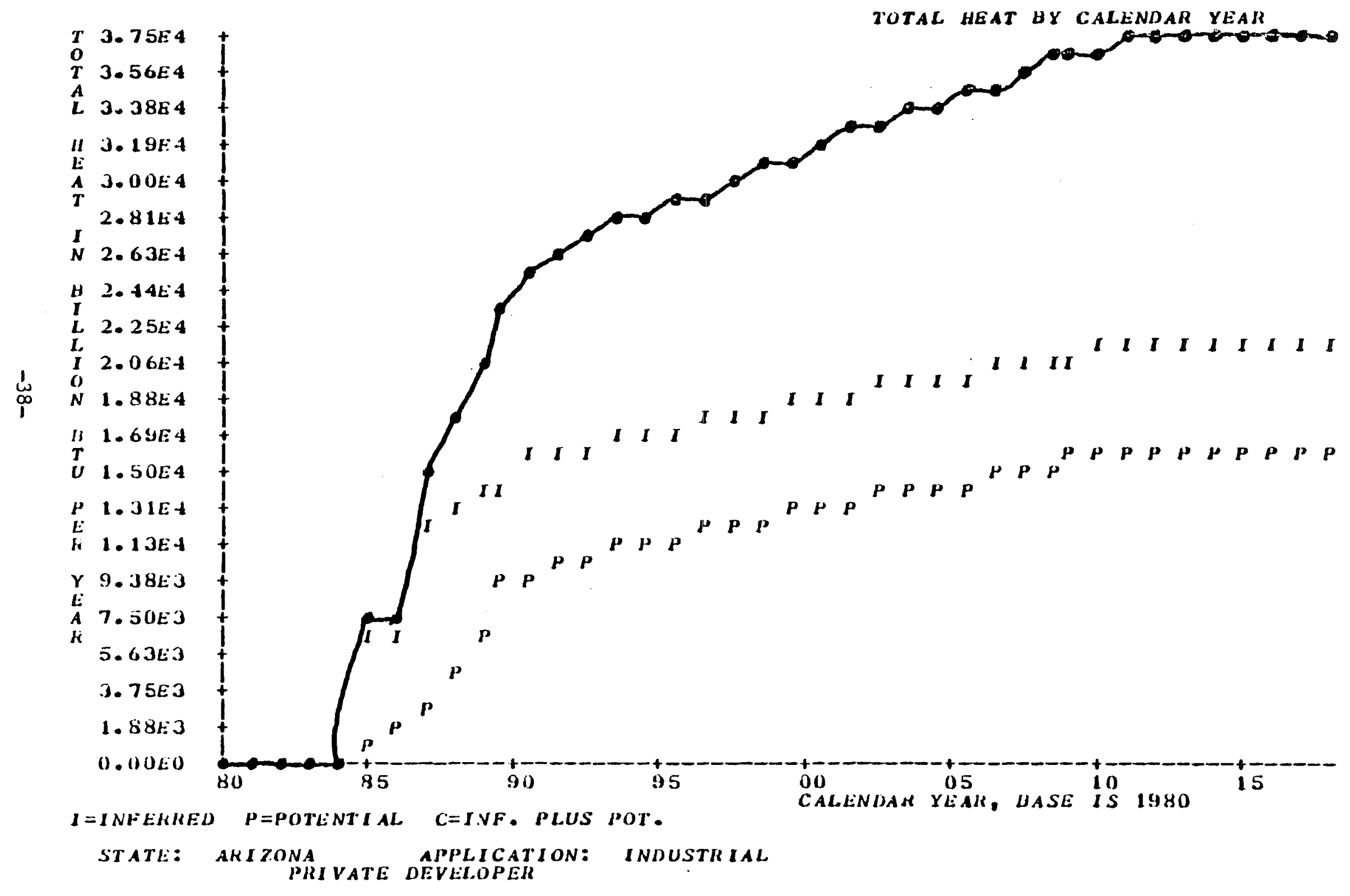

Figure 12: Projected Geothermal Heat on Line Under Private Development. Source: ' New Mexico Energy Institute 


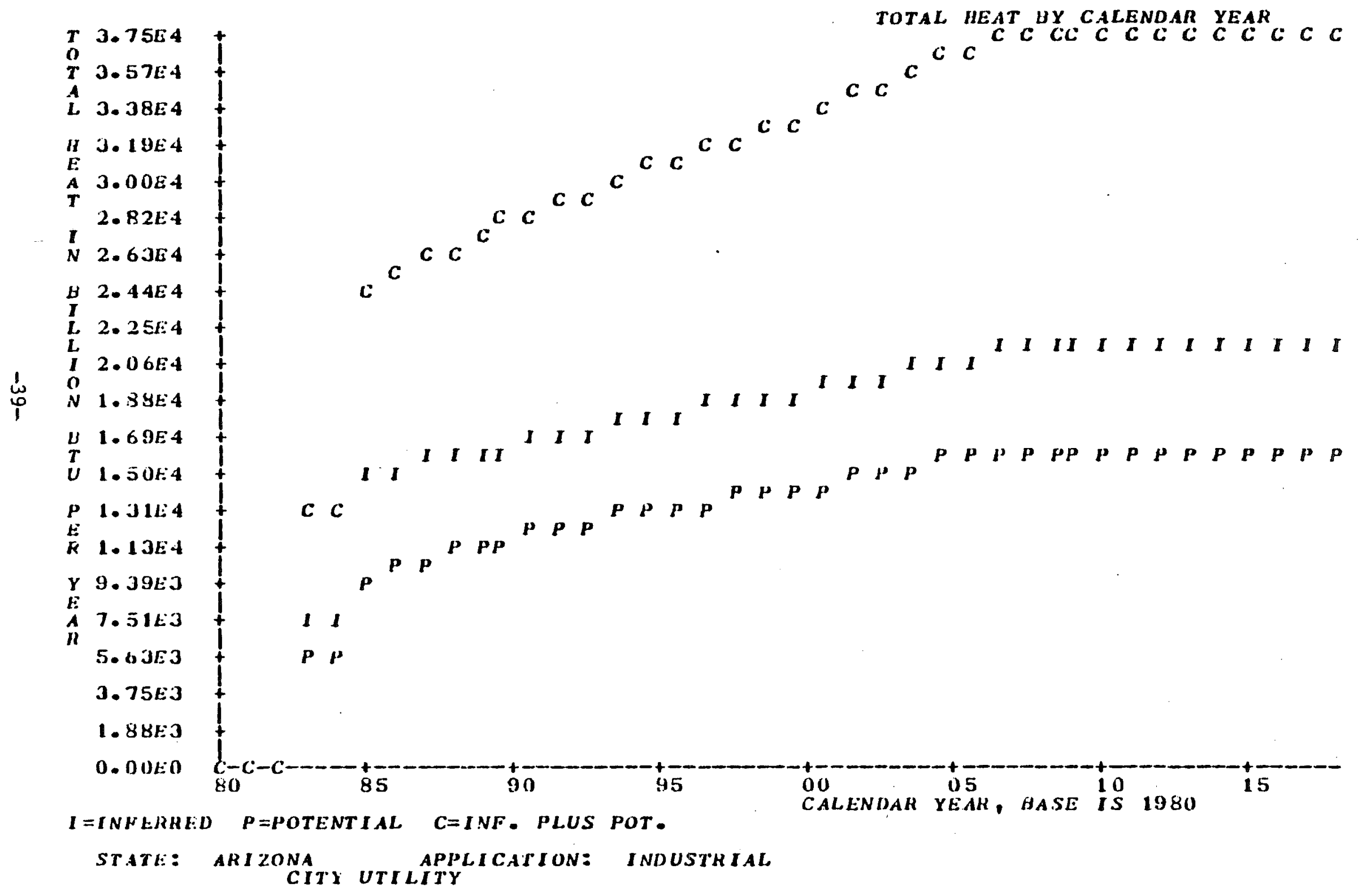

Figure 13: Projected Geothermal Heat on Line Under City Development. Snirre: Now Mexirn Fnerov Tnstitute 
In a second approach to identify potential users of geothermal energy, industries (1000 or more employees), industrial developments, existing and proposed shopping centers (100,000 sq ft or greater), housing developments, hospitals, colleges and high schools located within a five-mile radius of a known geothermal resource were identified. It is believed that a majority of Phoenix is underlain by a resource of low to moderate temperature; howeyer, the most promising areas are Mesa and Goodyear/Litchfield Park. Appendix B lists the facilities located near known geothermal resources in these two areas. The addresses of these facilities are also provided.

As shown in Figure 14, the Mesa and Goodyear/Litchfield Park areas are targeted for the greatest future growth in metropolitan Phoenix. Maricopa County officials believe that growth will occur most rapidly in the southeast during the 1980s and in the west and southwest during the 1990s. Therefore, these areas will have even more opportunity to use the existing geothermal potential in the future.

Last1y, the county's largest agribusiness industries and the process heat temperatures for the unit operations within each industry were identified in an attempt to define potential uses of geothermal energy for industrial processes. Table 16 lists the types of agribusiness industries in the county, most of which are located on or near a geothermal resource. Information on the specific heat temperatures needed in each of the unit operations within the industry enabled the previously assessed average geothermal reseryoir temperature for the county to be matched with the individual processes. Only those processes with large energy usage for which the demand for process heat could be supplied by geothermal energy are discussed.

The 1980 Directory of Arizona Manufacturers identified industries by $-40-$ 


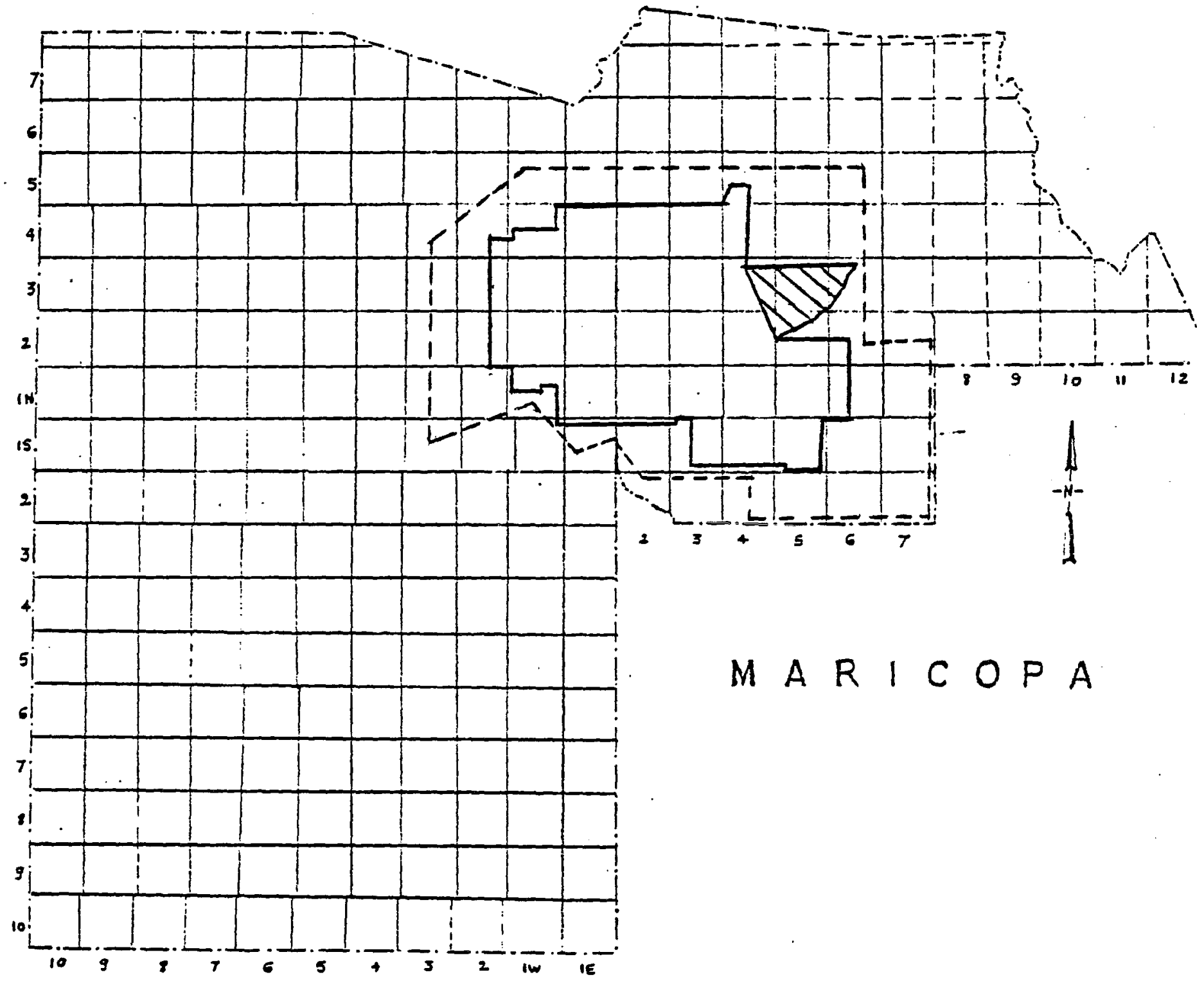

\footnotetext{
- GREATER PHOENIX IN 1979

--- GREATER PHOENIX IN 2000

$\Delta$ INDIAN LAND
}

Figure 14: Projected Growth of Metropolitan Phoenix. 
TABLE 16: AGRIBUSINESS IN MARICOPA COUNTY

\begin{tabular}{|c|c|c|c|c|c|c|c|c|c|c|c|}
\hline City & $\begin{array}{l}\text { Agri- } \\
\text { cultural } \\
\text { Chemicals }\end{array}$ & Feeds & $\begin{array}{l}\text { Citrus } \\
\text { Growers, } \\
\text { Packers, } \\
\text { Shippers }\end{array}$ & $\begin{array}{l}\text { Cotton } \\
\text { Products }\end{array}$ & $\begin{array}{l}\text { Cattle } \\
\text { Raising }\end{array}$ & $\begin{array}{l}\text { Dairy } \\
\text { Prod. }\end{array}$ & $\begin{array}{l}\text { Food } \\
\text { Prod. }\end{array}$ & $\begin{array}{c}\text { Meat } \\
\text { Packing }\end{array}$ & Seeds & Poultry & Vegetables \\
\hline \multicolumn{12}{|l|}{ Avondale } \\
\hline Buckeye & & & & 4 & & & & 1 & & & 1 \\
\hline Chandler & 1 & 2 & & 3 & & 1 & 1 & & & & \\
\hline Gilbert & & 1 & & 1 & & & & & & & 1 \\
\hline Glendale & 4 & 1 & 4 & 4 & & 2 & & & 3 & & 9 \\
\hline Goodyear & 2 & & & & & & & & & & \\
\hline Higley & & & 1 & & & & & & & & 1 \\
\hline Laveen & & & & & & 1 & & & & & \\
\hline Litchfield Park & & 1 & & 2 & & & & & & & 1 \\
\hline Mesa & 3 & 6 & 6 & . & & 1 & 3 & 2 & & & 1 \\
\hline Palo Verde & 1 & & & & & & & & & & \\
\hline Peoria & & & & 1 & & & & & & & \\
\hline Phoentx & 8 & 7 & 2 & 11 & 7 & 9 & 14 & 15 & 2 & 9 & 10 \\
\hline Scottsdale & 2 & & & & & & & & & & \\
\hline Tempe & 3 & & 3 & & & 2 & 1 & 1 & 1 & & \\
\hline Tolleson & 2 & 3 & & & & & & & & & 2 \\
\hline
\end{tabular}

Note: The numbers indicated represent the number of firms in the city under the speciffed agricultural sector. 
four-digit SIC codes and the Solar Energy Research Institute provided estimates of annual energy consumption as well as the process temperatures needed by these industries. Information on the specific heat temperatures needed in each of the operations within the industry was gathered from three principal sources: the Noyes Data Corporation publication entitled "EnergySaving Techniques for the Food Industry;" Drexel University's Energy Analysis of 108 Industrial Processes, Phase I of an Industrial Applications Study, 1979; and a Survey and Analysis of Solar Energy Process Heating Opportunities in Arizona prepared by the University of Arizona.

\section{Soft Drink Industry (SIC 2086)}

The soft drink industry in Maricopa County is primarily comprised of establishments engaged in manufacturing soft drinks and carbonated waters. Soft drink plants are typically located near concentrated population areas. While locational factors may affect energy use in some areas, this is not anticipated in Arizona. Total production of the industry is expected to continue to increase. Between 1972 and 1980 there has been a compounded annual growth rate of about 4.25 percent.

The soft drink industry has three basic plant types - those which both bottle and can, those which bottle only and those which can only. The most common plant within the industry is that which bottles. Major processes include mixing, bottle washing, cooling and filling.

The soft drink industry in total is an important energy-consuming industry within the Food and Kindred Products Group, ranking eighteenth in 1974 among the 47 industries within the group. Although the manufacture of soft drinks is not energy-intensive per unit of output (approximately 8,550 Btu per 192-ounce case), the volume throughout the industry necessitates 
relatively large fuel requirements. It is estimated that direct fuel is consumed by three primary functions: space heating (50 percent), bottle and can washing (20 percent) and intra-plant transport (30 percent). Bottle and can washing consumes about $19 \times 10^{10}$ Btu's/year. The temperatures used in this process are $60^{\circ} \mathrm{C}\left(140^{\circ} \mathrm{F}\right)$ to $82^{\circ} \mathrm{C}\left(180^{\circ} \mathrm{F}\right)$. This appears to be a very suitable opportunity for geothermal energy to replace conventional energy by supplying process heat.

Natural gas is the dominant energy source in the industry. In 1972, approximately 55 percent of all net energy was derived from natural gas. Fuel oils and purchased electricity accounted for 15 and 14 percent of all net energy, respectively; coal comprised 10 percent and other purchased fuels comprised approximately six percent of the energy sources.

Ready-Mix Concrete Industry (SIC 3273)

There are seven large firms within this industry in Maricopa County. The principal characteristic of the ready-mix concrete industry is that concrete is poured wet and allowed to set at ambient temperature at the job site. Therefore, most of the energy consumed in this industry is for transportation rather than for process heat. Electricity is used primarily in the crushing and mixing processes and fuel is consumed in transportation and mixing in transit. However, ready-mix concrete requires large quantities of hot water for cleaning, mixing and storage. Geothermal energy could possibly be used to heat the water needed for these processes. Further investigation of this sector is required before more definite statements can be made.

Beet Sugar Industry (SIC 2063)

The beet sugar industry is comprised of plants primarily engaged in $-44-$ 
manufacturing sugar from sugar beets. Beet sugar represents about 30 percent of all sugar consumed in the United States.

The various operations required for converting sugar beets into refined sugar are many and complex, but they are basically the same in all plants. The basic processes consist of slicing, diffusion, juice purification, evaporation, crystallization and recovery of the sugar. Intensive energy consumption is involved in the transporting, slicing and evaporating steps of the process and in the pumping of water and in air pollution control. In the direct manufacture of sugar there are no chemical changes that require significant amounts of energy. Almost all the energy-intensive steps in the manufacturing sequence involve physical changes or unit operations. These processes consume energy for crushing, pumping and centrifugation and for producing heat for solution, evaporation and drying. The steady engineering improvement of the equipment necessary to make these various operations function efficiently has gradually reduced the energy requirement for the sugar process itself; however, recent addition of water and air pollution control devices has tended to reduce the downward trend on energy requirements.

In general, the beet sugar plants located in the severe northern winter climates have a higher energy requirement than those in the milder climates, particularly those in California and Arizona. One example of this difference is that of storage. In the north, stored sugar beets freeze at the plants or at offsite beet dumps; thus, additional energy in the form of hot water and heat is required in the slicing and diffusing operation to thaw the beets for processing. In addition, some plants use as little as 2649 liters (700 gallons) while others use as much as 11,355 liters (3,000 gallons) of 
water effluent per ton of beets sliced. Disposal of this effluent under Environmental Protection Agency guidelines requires varying amounts of energy. In milder climates, irrigation disposal of water is feasible. In colder climates the effluent runs through several control processes which have added an estimated 25 percent to the electrical load of the sugar beet plant in recent years.

In 1972 it was estimated that 64.2 percent of the total energy consumed in this industry was provided by natural gas while coal proyided 26.6 percent. Six percent of the energy requirement was oftained from coke, a source of carbon dioxide. Both petroleum products were purchased; electricity provided a relatively small amount of energy.

In sumary, the temperatures required for the unit operations in the sugar beet industry are low, ranging between $24^{\circ} \mathrm{C}\left(75^{\circ} \mathrm{F}\right)$ and $121^{\circ} \mathrm{C}\left(250^{\circ} \mathrm{F}\right)$. The average assessed geothermal reservoir temperature is $110^{\circ} \mathrm{C}\left(230^{\circ} \mathrm{F}\right)$ in Maricopa County. Thus the potential for the use of geothermal heat is good, especially in the subprocess where the cascading of heat is used with all steam from boilers used in the evaporators. Maricopa County has one large plant in this industry which employs over 400 workers.

Ice Cream and Frozen Desserts (SIC 2024)

There are six firms in Maricopa County that fall under this category. The major energy-consuming steps in manufacturing tce cream and other frozen desserts are pasteurization, cooling and freezing. Although the freezing process is rather energy-intensive, the industry ranked thirty-fourth in total energy consumption in 1972 .

Electricity and natural gas were the major energy sources used by the $-46-$ 
industry in 1972. The primary direct uses of fuel are for whey drying (60 percent) and milk carton filling (30 percent). The remaining 10 percent is utilized for space heating.

In the ice cream industry 54 percent of the electrical energy is utilized for refrigeration. Processing equipment accounts for 18 percent of the electrical energy. The remainder is utilized for lighting, sales and garage and miscellaneous uses. The industry generates very little or none of its own electricity.

Specific processes and their respective required heat temperatures have not yet been identified. Further research in this industry is necessary.

Cottonseed Oil Mills (SIC 2074)

The cottonseed oil industry is the smallest within the fats and oil industry group in.terms of number of plants, value of shipments and number of employees. Plants are generally located near specific areas where cotton is grown. The cottonseed oil industry is comprised of plants primarily engaged in manufacturing non-edible vegetable oils. Maricopa County has two cottonseed oil plants.

Cottonseed oil mills consume about $6200 \mathrm{Btu} / \mathrm{lb}$ of cottonseed. Two types of operations are currently being used in the industry to process cottonseed: mechanical screw press and solvent extraction. The screw press operations are used by 75-80 percent of the industry. Table 17 presents an energy breakdown for each major step of the process.

Steam at about $135^{\circ} \mathrm{C}\left(275^{\circ} \mathrm{F}\right)$ is used for most of the conditioning and extraction process. The toaster solventizer must reach a temperature of $215^{\circ} \mathrm{C}\left(419^{\circ} \mathrm{F}\right)$. Because the required temperatures are greater than 
TABLE 17: COTTONSEED OIL MILIS ENERGY END-USE REQUIREMENTS

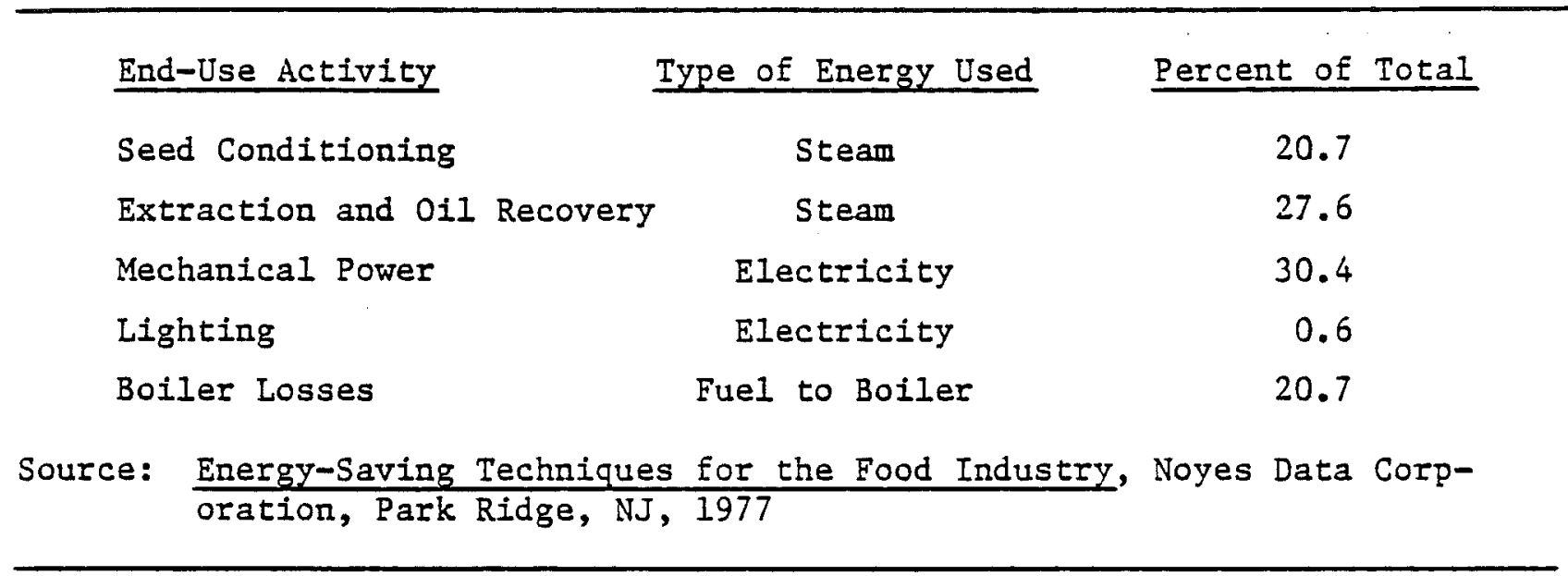

the average assessed geothermal reservoir temperature in Maricopa County, geothermal heat would best be used for preheating the boiler water and the solventizer. The use of $110^{\circ} \mathrm{C}\left(230^{\circ} \mathrm{F}\right)$ water could provide a substantial fossil fuel savings for the extraction and conditioning processes and reduce boiler losses. In addition, geothermal heat could be used to keep the oil at the proper consistency while in storage.

Animal and Marine Fats and Oils (SIC 2077)

Four firms within Maricopa County are within this industrial classification. The animal rendering plants consume about $1900 \mathrm{Btu} / \mathrm{lb}$ of animal base product in the form of steam and hot water. Table 18 presents a summary of operations in the production of fats and oils.

As was the case with cottonseed oil production, geothermal energy would best be used to preheat boiler feed water. Hot water could also be used for production, cleanup and storage. 
TABLE 18: FATS AND OILS ENERGY END-USE REQUIREMENTS

\begin{tabular}{lcc}
\hline End-Use Activity & Type of Energy Used & Percent of Total \\
\cline { 2 - 3 } Production \& Cleanup & Hot Water/Steam & 19 \\
Rendering & Hot Water/Steam & 19 \\
Mechanical Power & Electricity & 24 \\
Lighting & Electricity & 2 \\
Boiler Losses & Fuel to Boiler \\
Direct Use & Fuel & 28 \\
Source: & Energy-Saving Techniques for the Food Industry, Noyes Data Corp- \\
\cline { 2 - 3 } oration, Park Ridge, NJ, 1977 & $\frac{8}{100}$ \\
\hline
\end{tabular}

\section{Plating and Polishing Industry (SIC 3471)}

There are four firms in Maricopa County within this industrial class. A study completed by the University of Arizona Energy Management and Policy Group indicates that various process heat temperatures for the unit operations are necessary in the Plating and Polishing Industry. The subprocess of plating baths is the only process identified for which geothermal energy has potential. This process requires heat temperatures between $54^{\circ} \mathrm{C}\left(130^{\circ} \mathrm{F}\right)$ and $102^{\circ} \mathrm{C}\left(215^{\circ} \mathrm{F}\right)$. Thus, given that the average geothermal reservoir temperature in the county is $110^{\circ} \mathrm{C}\left(230^{\circ} \mathrm{F}\right)$, geothermal energy potentially could replace electricity as the industry's main energy source. 


\section{Appendix A}

The New Mexico Energy Institute at New Mexico State University has developed a computer simulation model, BTHERM, to assess the economic feasibility of residential and commercial district space heating, hot water heating and industrial process heating using low temperature geothermal energy. Another model, CASH, was developed to depict the growth of geothermal energy on line over the next 40 years as a function of price of competing energy sources. A major assumption of these models is that geothermal energy must be price-competitive with the lowest-cost conventional energy source in order to assure market capture.

Development of a geothermal resource is characterized by large capital outlays, but a long-term geothermal investment has the potential to provide relatively inexpensive energy at a stable price. Unlike natural gas and electricity, however, geothermal energy is an unknown energy involving certain risks such as price and reservoir life and the need for back-up systems. An analysis of the costs and economic competitiveness of geothermal energy must take these uncertainties into account. Thus, costs may be overestimated so that the benefits will not be overstated.

The BTHERM computer simulation model models the residential, commercial and industrial sectors of a typical city, each sector having unique energy costs and energy system physical parameters as well as different growth rates. The model possesses the ability to model each sector individually and can analyze the application of geothermal energy to new growth only, to conversion of existing structures or to a combination of both. The model also has the capability to model both private and city-owned utility development of the geothermal resource. 
Output of the model includes the levelized price per million Btu of delivered energy, the discounted present value of investment necessary and the undiscounted values of investments for policy studies, Also, from input of the price and price growth rate of conventional energy, the model determines the discounted or undiscounted values for federal and state taxes, tax credits, royalty rates, property taxes and consumer savings due to conversion from conventional energy to geothermal.

Certain limitations of the model have already heen suggested. Costs, for example, may be overestimated due to safeguards built into the model to take into account the risks associated with geothermal energy. This overestimation of costs might result in the exclusion of a potential use of geothermal energy. Another limitation is that the price of natural gas is taken as the price of competitive (conventionall energy, but not all users have access to natural gas.

The output of the model is not a substitute for detailed engineering design studies but it is useful for determining order-of-magnitude costs and potential benefits of geothermal energy development. 
POTENTIAL USERS OF GEOTHERMAL ENERGY IN METROPOLITAN PHOENIX

Type of Development

Industry

Goodyear Aerospace Corporation

(Div. Goodyear Tire \& Rubber Co.)

Litchfield Boulevard

Litchfield Park

Spring City Knitting Co.

(Div. Spring City Knitting Co.2

6322 W. Myrtle

Glendale

Luke AFB

Litchfield Park

Industrial Park Developments

Falcon Field Industrial Park

McKellips and Falcon Drive

Mesa

Gardner Industrial Park

N. Greenfield near Falcon Field

Mesa

Eaton Glendale Industrial Center

N. 51st \& West Luke Avenues

Glendale

Glendale East

Montebello to Luke Avenues

51st to 53rd Avenues

Glendale

Liberty Park North

Dysart \& Olive Avenue

Glendale 
Appendix B (continued)

Potential Users of Geothermal Energy in Metropolitan Phoenix

Type of Development

Industrial Park Developments (continued)

Blasdale Development

McDowell to Yuma Roads

Southern Pacific RR to Reems Road

Goodyear

Litchfield Park Properties

McDowell to Western

Dysart to Cotton Lane

Rayner Industrial Site

$2 \frac{1}{2}$ mi SW of Goodyear on U.S. 80

Large-scale Developments -- Underway/Proposed

Fountain of the Sun

Broadway \& 80th Street

Mesa

Knoell Mesa

Gilbert \& Southern

Mesa

Leisure World Golden Hills

Baseline \& Bush Highway

Mesa

OId West Village III

Gilbert and Southern

Mesa

Ranch Mesa

Baseline \& Gilbert Roads

Mesa

Sunland Village

Broadway \& Greenfield Roads

Mesa

Chapparal

55 th Averiue \& Bell Road

Glendale

Litchfield Park

Litchfield Park 
Appendix B (continued)

Potential Users of Geothermal Energy in Metropolitan Phoenix

Type of Development

Large-scale Developments -- Underway/Proposed (Continued)

Maryvalle Terrace

Maryvalle

Royal Estates West, Unit 5

59 th Avenue \& Thunderbird

Sarival Gardens

$16644 \mathrm{~W}$. Lower Buckeye

Goodyear

Thunderbird Palms

51st Avenue \& Thunderbird

West Bluff

63rd-67th. Avenues \& Cactus

Westree

59 th Avenue \& Greenway Road

Winnwood Estates

55 th Avenue \& Cholla Road

Glendale

\section{Existing Shopping Centers}

Apache Plaza

Apache Trail and Power Road

Mesa

Buckhorn Plaza Shopping Center Apache Trail and Recker Road

Mesa

Riviera Plaza

Gilbert and University

Mesa

Smitty's

Apache Trail and Greenfield Road

Mesa 
Appendix B (Continued)

Potential Users of Geothermal Energy in Metropolitan Phoenix

Type of Development

Existing Shopping Centers (Continued)

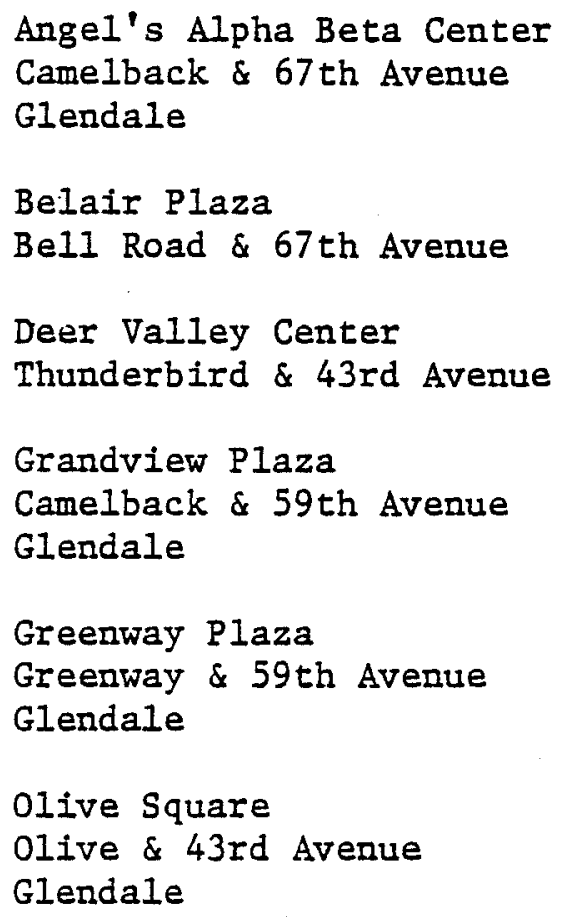

Shopping Centers Under Construction

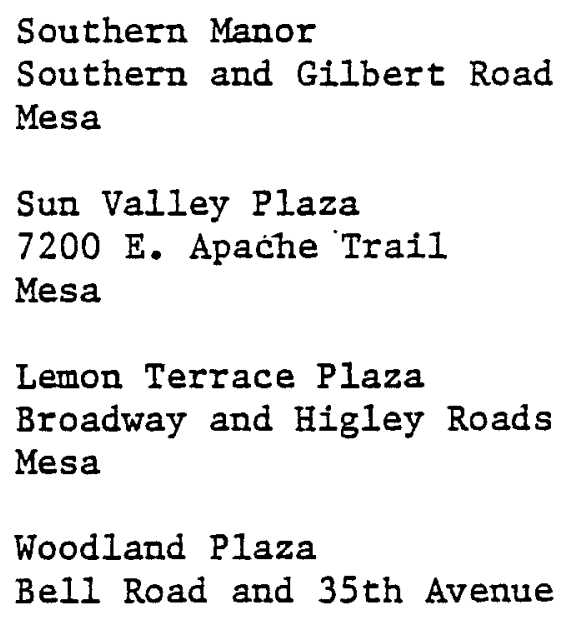

High Schools

Apollo High School

8045 N. 47 th Avenue

Glendale 
Appendix B (Continued)

Potential Users of Geothermal Energy in Metropolitan Phoenix

Type of Development

High Schools -- (Continued)

Cortez

8828 N. 31st Avenue

Phoenix

Glendale

6216 W. Glendale Avenue

Glendale

Greenway

3930 W. Greenway

Glendale

Moon Valley

3625 W. Cactus

Glendale

Washing ton

2217 W. Glendale

Phoenix

Colleges and Graduate Schools

Glendale Community College

$6000 \mathrm{~W}$. Olive Avenue

Glendale

American Graduate School of

International Management

59 th Avenue and Greenway Road

Glendale

Hospitals

Glendale Samaritan Hospital

6010 W. Northern Avenue

Glendale

Maryvale Samaritan Hospital

5102 W. Campbe11

Phoenix

Phoenix Baptist Hospital

6025 N. 20th Avenue

Phoenix

Source: Inside Phoenix, 1981, Phoenix Newspapers, Inc. 


\section{BIBLIOGRAPHY}

References used in preparing the Area Development Plans

Arizona Agricultural Statistics 1978, 1979: Phoenix, Arizona, Arizona Crop and Livestock Reporting Service, 68 p.

Arizona Community Profiles, 1981: Phoenix, Arizona, Research Program, Arizona Office of Economic Planning and Development.

Arizona Statistical Review, 1979: Phoenix, Arizona, Valley National Bank of Arizona, $72 \mathrm{p}$.

Brown, K., 1978, Industrial Process Heat Demand Balance: Golden, Colorado, Solar Energy Research Institute, unpublished draft.

Climatograph of U.S. No. 81 Arizona, 1978: Asheville, North Carolina, National Climate Center.

Dunn, D. and Cox, D.C., 1979, Papers in Community Development No. 2 - SocioEconomic Indicators for Small Towns: Tucson, Arizona, Rural Information Center, $58 \mathrm{p}$.

Energy Analysis of 108 Industrial Processes, 1979: Philadelphia, Pennsylvania, Drexel University.

Energy-Saving Techniques for the Food Industry, 1977, M.E. Casper, editor: Park Ridge, New Jersey, Noyes Data Corporation, 657 p.

Frank, H.J., 1977, Arizona Energy Inventory: 1977: University of Arizona, Tucson, $100 \mathrm{p}$.

Gerber, L.A., Worden, M.A., and Dunn, D., 1980, Papers in Community Development No. 5 - Safford, Arizona: A Trade Area Analysis: Tucson, Arizona, Rural Information Center, 76 p.

Gibson, L.J.; Worden, M.A., and Solot, M.S., 1979, Papers in Community Development No. 1 - A Citizen's Handbook for Evaluating Community Impacts: Tucson, Arizona, Rural Information Center, 65 p.

Hodgson, M.L., 1978, Arizona Job Scene 1985: A Labor Market Information Publication of the Arizona Department of Economic Security, $133 \mathrm{p}$. 
Industrial Waste Heat Survey, 1978, Rocket Research Company .

Inside Phoenix 1979, 1979: Phoenix, Arizona, Phoenix Newspapers, Inc., 152 p.

Inside Phoenix 1981, 1981: Phoenix, Arizona, Phoenix Newspapers, Inc., 128 p.

1981 Directory of Arizona Manufacturers, 1981: Phoenix, Arizona, Phoenix Metropolitan Chamber of Commerce, 200 p.

Phase II - Arizona State Water Plan: Alternative Future, 1977: Phoenix, Arizona, Arizona Water Commission, 145 p.

Population, Employment and Income Projections for Arizona Counties 1977 2000, July 1978 \& 1979: Arizona Department of Economic Security.

Population Estimates of Arizona as of July 1, 1979: Phoenix, Arizona, Arizona Department of Economic Security Report No. 12, 66 p.

Statistical Report for Financial Analysis 1969 - 1979: Phoenix, Arizona, Arizona Public Service Company, 24 p.

Stone, C., 1980, Preliminary Assessment of the Geothermal Potential at the Papago Farms, Papago Indian Reservation, Arizona: State of Arizona Bureau of Geology and Mineral Technology Open-File Report 80-6, 62 p.

Stone, C., 1981, A Preliminary Assessment of the Geothermal Resource Potential of the Yuma Area, Arizona: State of Arizona Bureau of Geology and Sineral Technology Open-File Report 81-4, 28 p.

Survey and Analysis of Solar Energy Process Heat Opportunities in Arizona, 1979: University of Arizona, Department of Nuclear Energy, Energy Management and Policy Analysis Group, Final Report prepared for Arizona Solar Energy Research Commisston under Office of Economic Planning and Development Contract No. 458-78

Swanberg, C.A., Morgan, P., Stoyer, C.H., and others, 1977, An Appraisal Study of the Geothermal Resources of Arizona and Adjacent Areas in New Mexico and Utah and Their Value for Desalination and other Uses: New Mexico Energy Institute Report No. 6, 76 p. 
Tucson Trends 1980, 1980: Tucson, Arizona, Valley National Bank of Arizona and Tucson Newspapers Inc, $88 \mathrm{p}$.

Witcher, J.C., 1979, Proven, Potential and Inferred Geothermal Resources of Arizona and Their Heat Contents: State of Arizona Bureau of Geology and Mineral Technology Open-File Report $79-5,65 \mathrm{p}$.

- Witcher, J,C., 1981, Geothermal Energy Potential of the Lower San Francisco River Region, Arizona: U.S. Geological Survey Open-File Report 81-7, $135 \mathrm{P}$. 
